\title{
External morphology of the adult of Dynamine postverta (Cramer) (Lepidoptera, Nymphalidae, Biblidinae) and patterns of morphological similarity among species from eight tribes of Nymphalidae
}

\author{
Luis Anderson Ribeiro Leite ${ }^{1,2}$, Mirna Martins Casagrande ${ }^{1,3}$ \& Olaf Hermann Hendrik Mielke ${ }^{1,4}$
}

'Departamento de Zoologia, Setor de Ciências Biológicas, Universidade Federal do Paraná, Caixa Postal 19020, 81531-980 Curitiba-PR, Brasil.
${ }^{2}$ landersonrleite@gmail.com, ${ }^{3}$ mibras@ufpr.br, ${ }^{4}$ omhesp@ufpr.br ABSTRACT. External morphology of the adult of Dynamine postverta (Cramer) (Lepidoptera, Nymphalidae, Biblidinae) and
patterns of morphological similarity among species from eight tribes of Nymphalidae. The external structure of the integument of
Dynamine postverta postverta (Cramer, 1779) is based on detailed morphological drawings and scanning electron microscopy. The
data are compared with other species belonging to eight tribes of Nymphalidae, to assist future studies on the taxonomy and
systematics of Neotropical Biblidinae.

KEYWORDS. Abdomen; head; Insecta; morphology; Papilionoidea; thorax.

Nymphalidae is a large cosmopolitan family of butterflies, with about 7,200 described species (Freitas \& Brown Jr. 2004) and is perhaps the most well documented biologically (Harvey 1991; Freitas \& Brown Jr. 2004; Wahlberg et al. 2005). The systematic relationships are still somewhat unclear with respect to its subfamilies, tribes and genera, and even after more than a century of studies on these groups, these relationships still seem to confuse many who set out to study the family (Brower 2000; Wahlberg et al. 2003). Phylogenetic studies in Nymphalidae have been treated by several authors, with results varying according to sampling and methods, directly reflecting on the various nymphalid classifications, where many of the subfamilies and tribes are still vaguely defined and the monophyly supported by few characters (Freitas \& Brown Jr. 2004).

Biblidinae, formerly a tribe of Limenitidinae (Harvey 1991; Neild 1996), was elevated to subfamily, after molecular and morphological studies which indicated its independence, with the monophyly especially supported by the presence of the hypandrium in males, which is a modification of the eighth sternum (Brower 2000; Wahlberg et al. 2003; Freitas \& Brown Jr. 2004). Altogether, 11 subfamilies represented by 27 tribes are recognized by Lamas (2004), with Biblidinae divided into two tribes, the current monophyletic tribe Cyrestini of Limenitidinae and Biblidini, the current Biblidinae according to Freitas \& Brown Jr. (2004).

Dynamine Hübner, [1819], the largest genus of Biblidinae (Lamas 2004; Brévignon 2008; Willmott \& Hall 2010), includes 41 Neotropical species. Dynamine postverta (Cramer, 1779), the type species of the genus, is distributed throughout the continental Neotropical region, including the islands of Trinidad and Tobago and Curacao, and may occur from sea level to 1,400 m (DeVries 1987; Neild 1996; Miller et al. 1999; Lamas 2004). It shows sexual dimorphism, easily ob- served in dorsal view (Figs. 1-4). Two subspecies are recognized according to Lamas (2004), Dynamine postverta postverta (Cramer, 1779) distributed in South America and Dynamine postverta mexicana d'Almeida, 1952 with a distribution restricted to Central America. Several species surveys and other studies cite this species as Dynamine mylitta (DeVries 1987; Mielke 1994; Miller et al.1999; Freitas \& Brown, Jr. 2004; Iserhard \& Romanowski 2004), which is a junior synonym (Lamas 1995).

Studies focusing on the complete morphological description of adult butterflies were included in several publications for Nymphalidae. However, if the number of subfamilies is considered (sensu Lamas 2004), less than half of them are described through morphological studies of the head, thorax and abdomen, among them, Danainae (Ehrlich 1958); Ithomiinae (Bizarro et al. 2003a,b,c); Morphinae (Casagrande 1979a,b,c; Bilotta 1992; 1994a,b); Charaxinae (Mielke et al. 2004a,b,c; Dias et al. 2010) and Heliconiinae (Paluch et al. 2008).

Considering the importance of detailed morphological descriptions for taxonomic and systematic studies of Lepidoptera (Leite et al. 2010a) and the absence of such studies for the Biblidinae, this paper aims to detail the external morphology in both sexes of Dynamine postverta postverta (Cramer,1779) and compare the results with previously published morphological descriptions of other Nymphalidae, thus contributing to the systematic knowledge of the family, and assisting future research on the Neotropical Biblidinae.

\section{MATERIAL AND METHODS}

Dynamine postverta postverta specimens of both sexes $(\mathrm{n}=20$ males and 10 females) were used for this study, from collections in the northwest region of the State of Paraná: 

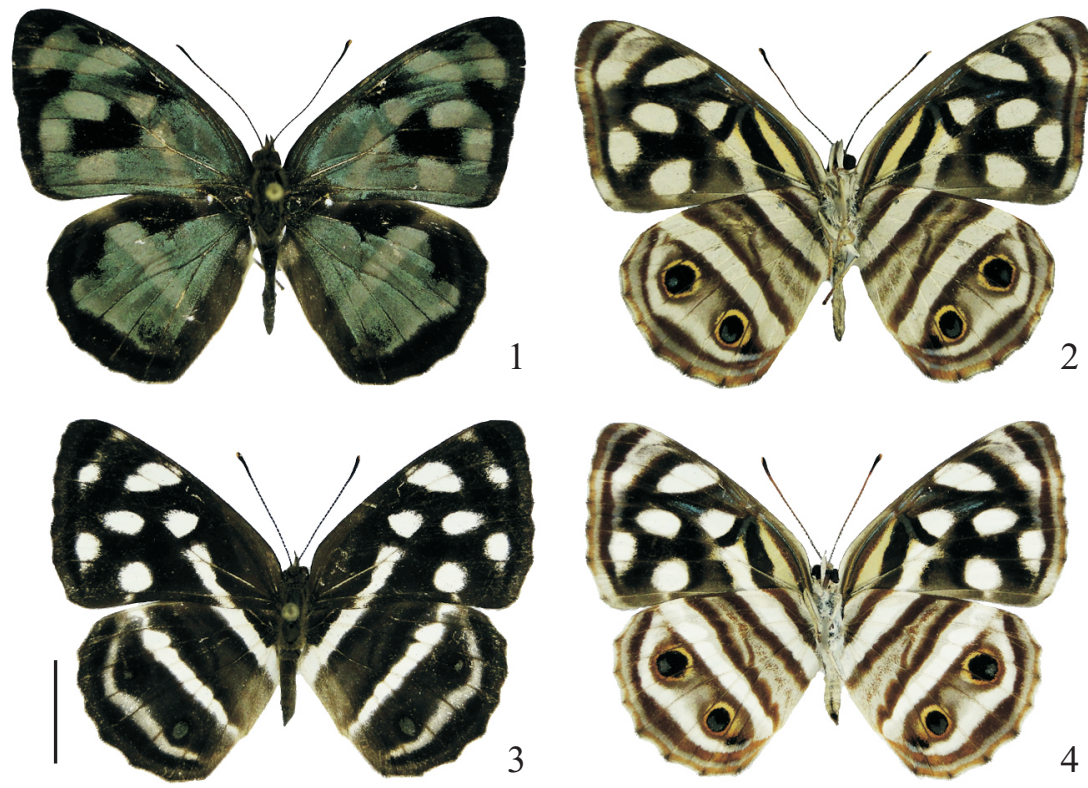

Figs. 1-4. Dynamine postverta postverta. 1, 2. Male: 1, dorsal view; 2, ventral view; 3, 4. Female: 3, dorsal view; 4, ventral view. Scale bar 1 cm.

Loanda, RPPN Fazenda Matão (22 ${ }^{\circ} 55^{\prime} \mathrm{S}, 52^{\circ} 53^{\prime} \mathrm{W}, 464 \mathrm{~m}$ ); Terra Rica, Parque Municipal dos Três Morrinhos (2246’S, 52 39'W, $601 \mathrm{~m}$ ); Planaltina do Paraná, RPPN Duas Barras $\left(23^{\circ} 11^{\prime} \mathrm{S}, 50^{\circ} 00^{\prime} \mathrm{W}, 266 \mathrm{~m}\right)$; Paranavaí $\left(22^{\circ} 45^{\prime} \mathrm{S}, 52^{\circ} 26^{\prime} \mathrm{W}\right.$, $369 \mathrm{~m})$ and Diamante do Norte, Estação Ecológica do Caiuá (2236'S, 52 51'W, $273 \mathrm{~m}$ ).

When possible, the specimens were sacrificed in a killing jar, for the preservation of structures. The head, thorax, abdomen and respective appendages were boiled in $10 \%$ potassium hydroxide $(\mathrm{KOH})$ to soften the structures and facilitate the removal of scales. The wings were removed from the dry specimens and then cleared in Petri dishes, being first immersed in $70 \%$ alcohol and then in sodium hypochlorite $(\mathrm{NaOCl})$ to complete the clearing process, then were again submerged in $70 \%$ alcohol for neutralization and subsequently placed on absorbent paper to dry. For the study of the genitalia, the abdomen was dissected by opening the pleural region longitudinally. Illustrations were made with a stereoscopic microscope coupled to a camera lucida. Further details of some structures were obtained using photographs from a scanning electron microscope following standard procedures (Kaminski et al. 2008; Leite et al. 2010a).

Comparative aspects were treated based on other similar studies of the Nymphalidae (Tables I and II), using morphological drawings and descriptions in the referred studies, focusing on one species from each tribe, according to the classification proposed by Lamas (2004), as follows: Morpho helenor violaceus Fruhstorfer, 1912 (Morphinae, Morphini) (Bilotta 1992, 1994a,b); Caligo beltrao (Illiger, 1801) (Morphinae, Brassolini) (Casagrande 1979a,b,c); Danaus plexippus (Linnaeus, 1758) (Danainae, Danaini) (Ehrlich 1958); Agrias claudina anneta (Gray, 1832) (Charaxinae, Preponini) (Mielke et al. 2004a,b,c); Memphis moruus stheno (Prittwitz, 1865) (Charaxinae, Anaeini) (Dias et al. 2010);
Actinote melanisans Oberthür, 1917 (Heliconiinae, Acraeini) (Paluch et al. 2008) and Thyridia psidii cetoides (Rosenberg $\&$ Talbot, 1914) (Ithomiinae, Mechanitini) (Bizarro et al. 2003a,b,c).

The terminology used mostly follows Ehrlich (1958), with modifications from the classical and recent literature for the Lepidoptera (Snodgrass 1935; Matsuda 1965; 1970; 1976; Casagrande 1979a,b,c; Scoble 1992; Mielke et al. 2004a,b,c; Paluch et al. 2008; Leite et al. 2010a,b; 2011).

\section{RESULTS}

\section{Head (Figs. 5-12, 43-52)}

Hypognathous, with prominent globular shaped compound eyes in frontal view, width is greater than height, and hairy, with setae distributed over most of its surface (Fig. 46). Narrow paraocular area between the ocular margin and the laterofacial suture which separates it from the frontoclypeal region. This suture is slightly closer to the frontoclypeal region at the height of the anterior tentorial pit above, and beginning at the subgena is closer to the ocular margin. Quadrangular shaped fronto-clypeus, located between the compound eyes, is lower than their height. Transclypeal band is ventral to the fronto-clypeus and separated from it by a thin less sclerotized strip, being separated from the subgena by the clypeogenal section of the laterofacial suture, where the anterior tentorial pit is found, adjacent as an invagination of the integument (Fig. 47). Clypeolabral suture present, separating the transclypeal band from the labrum. In superior view, the fronto-clypeus is delimited by the transfrontal suture which separates it from the vertex.

Dorsally, vertex as a small dorsomedian subrectangular area, delimited anteriorly at the fronto-clypeus by the transfrontal suture, laterally by the antennal alveoli, and pos- 

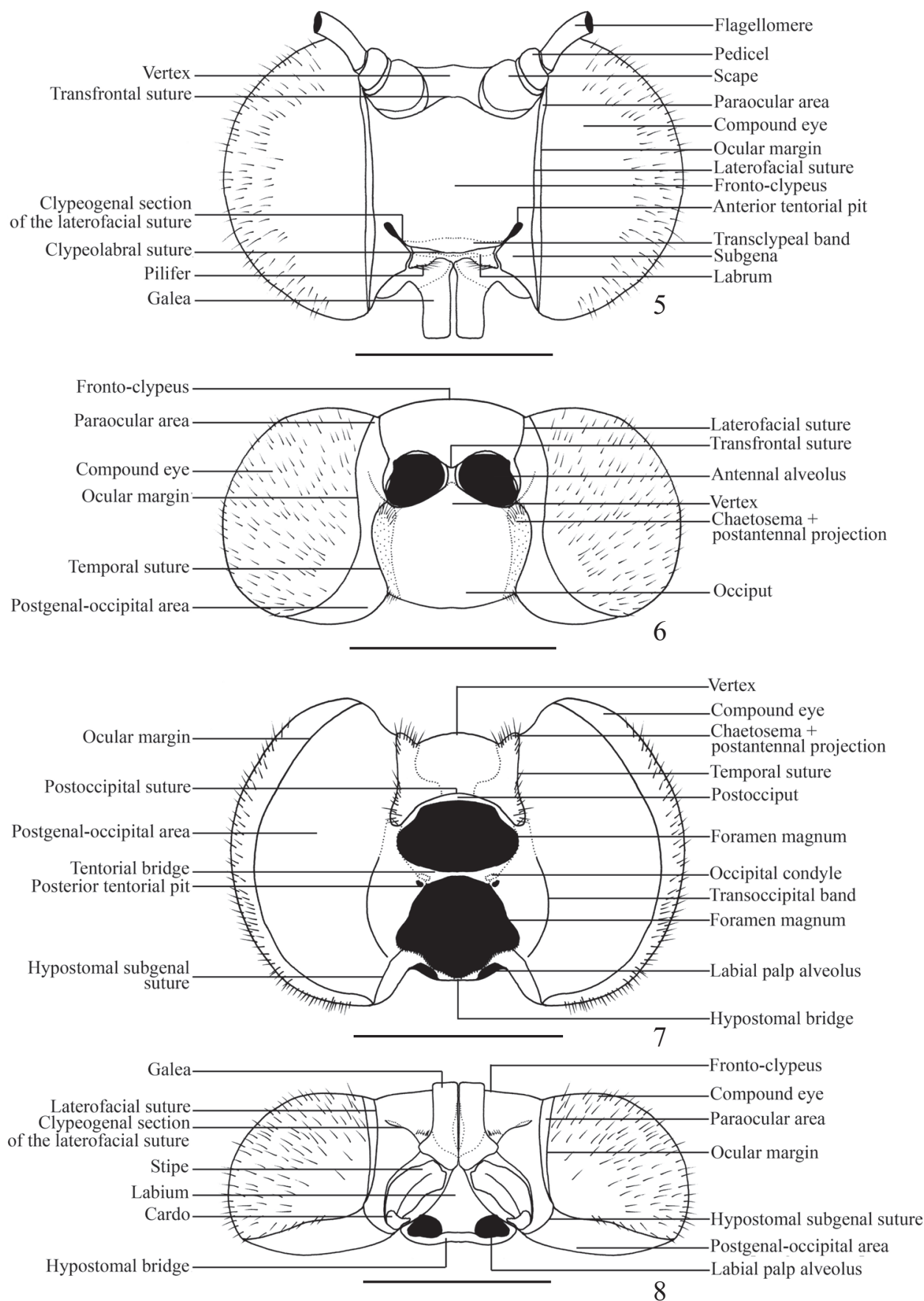

Figs. 5-8. Dynamine postverta postverta. Head: 5, frontal view; 6, dorsal view; 7, posterior view; 8, ventral view. Scale bar $1 \mathrm{~mm}$.

teriorly by the occiput. Laterofacial suture ends at the lateroposterior margin of the antennal alveolus. Postantennal projection with the chaetosema evident and positioned posteriorly to the antennal alveolus (Fig. 52), separated from the postgenal-occipital area by the temporal suture which goes to the posterior region of the head. Paraocular area contiguous with the ocular margin and extended posteriorly towards the postgenal-occipital area.

In posterior view, occupying most of the posterior area of the head, the postgenal-occipital area situated between the ocular margin and the foramen is evident. Transoccipital band located on the lower half of the postgenal-occipital area and next to the foramen. This band separates regions with different degrees of sclerotization, with less sclerotization in the area closest to the foramen. Hypostomal subgenal suture separates the postgenal-occipital area from the hypostomal bridge and ends at the lateroinferior part of the foramen. Posterior tentorial pit (Fig. 48), just below the occipital condyle, along the posterior edge of the inferior part of the foramen. The foramen magnum is divided into two regions, delimited superiorly by the postocciput, medially divided by tentorial bridge, where the occipital condyle is located, laterally by 
Table I. Morphological differences among species in different subfamilies and tribes of Nymphalidae.

\begin{tabular}{|c|c|c|c|c|}
\hline Characters & $\begin{array}{l}\text { Dynamine postverta } \\
\text { Biblidinae-Biblidini }\end{array}$ & $\begin{array}{c}\text { Morpho helenor } \\
\text { Morphinae-Morphini }\end{array}$ & $\begin{array}{c}\text { Caligo beltrao } \\
\text { Morphinae-Brassolini }\end{array}$ & $\begin{array}{l}\text { Danaus plexippus } \\
\text { Danainae-Danaini }\end{array}$ \\
\hline Compound eye & pilous & glabrous & glabrous & glabrous \\
\hline Number of antenna articles (average) & 40 & 50 & 47 & 43 \\
\hline Fronto-clypeus & subquadrangular & subrectangular & subrectangular & oval \\
\hline Paraocular area from the subgena & narrow & narrow & continuous & wider \\
\hline Clypeogenal section of the laterofacial suture & $\begin{array}{l}\text { short, without contact with } \\
\text { the laterofacial suture }\end{array}$ & $\begin{array}{l}\text { elongated toward the dorsal } \\
\text { region }\end{array}$ & $\begin{array}{l}\text { elongated toward the } \\
\text { dorsal region }\end{array}$ & $\begin{array}{l}\text { contiguous with the } \\
\text { laterofacial suture }\end{array}$ \\
\hline Transclypeal band & presence & absence & absence & presence \\
\hline Basal segment of the labial palp & short & short & short & short \\
\hline Rudimental maxillary palp & absence & presence & presence & presence \\
\hline Cervical region- articulation with the head & $\begin{array}{l}\text { very elongated compared } \\
\text { to the posterior ventral } \\
\text { expansion }\end{array}$ & $\begin{array}{l}\text { short compared to the } \\
\text { posterior ventral expansion }\end{array}$ & $\begin{array}{l}\text { short compared to the } \\
\text { posterior ventral } \\
\text { expansion }\end{array}$ & $\begin{array}{l}\text { similar length compared } \\
\text { to the posterior ventral } \\
\text { expansion }\end{array}$ \\
\hline Prothoracic leg on males & glabrous & with bristles & glabrous & glabrous \\
\hline Tegula & $\begin{array}{l}\text { with anterior ventral } \\
\text { expansion }\end{array}$ & $\begin{array}{l}\text { without anterior ventral } \\
\text { expansion }\end{array}$ & $\begin{array}{l}\text { with anterior ventral } \\
\text { expansion }\end{array}$ & $\begin{array}{l}\text { with anterior ventral } \\
\text { expansion }\end{array}$ \\
\hline Dorsoanterior margin of the scutellum II & $\begin{array}{l}\text { in the same height of the } \\
\text { postalar plate }\end{array}$ & $\begin{array}{l}\text { in the same height of the } \\
\text { postalar plate }\end{array}$ & $\begin{array}{l}\text { in the same height of the } \\
\text { postalar plate }\end{array}$ & $\begin{array}{l}\text { in the same height of the } \\
\text { postalar plate }\end{array}$ \\
\hline Dorsoanterior margin of the scutellum III & rounded & rounded & straight & rounded \\
\hline Furcasterum & without lateral lamellae & without lateral lamellae & without lateral lamellae & without lateral lamellae \\
\hline Discal cell of the hindwing & closed & opened & closed & closed \\
\hline Odoriferous hairpencils on the wing & absence & absence & absence & absence \\
\hline Humeral vein (h) & simple & simple & simple & simple \\
\hline Curvature of the humeral vein (h) & toward to the apex & toward to the basis & toward to the basis & toward to the basis \\
\hline Basal cell & absence & presence & presence & presence \\
\hline Sclerotized lobe preceding the tergo-pleural bar & presence & absence & absence & presence \\
\hline Hypandrium & presence & absence & absence & absence \\
\hline Anterior projection of the saccus & Long and straight & short and dorsally curved & short and straight & short and straight \\
\hline Gnathos & fused & absence & free & absence \\
\hline Aedeagus & cylindrical & anteriorly wider & cylindrical & anteriorly wider \\
\hline Shape of the fultura inferior & $\mathrm{Y}$ & $\mathrm{V}$ & oval & triangular \\
\hline $\begin{array}{l}\text { Distal portion of the anteapophysis external on } \\
\text { the integument }\end{array}$ & presence & absence & absence & absence \\
\hline Signa & absence & presence & presence & presence \\
\hline $\begin{array}{l}\text { Length of the corpus bursae compared to the } \\
\text { ductus bursae }\end{array}$ & similar & larger & larger & larger \\
\hline Shape of the corpus bursae ventrally & rounded & oval & rounded & oval \\
\hline
\end{tabular}

the postgenal-occipital area, and inferiorly by the hypostomal bridge. The temporal suture extends to the upper half of the foramen, having a convex aspect from this point on, where it merges with the postoccipital suture.

In lateral view, the compound eye stands out, occupying most of the head. The fronto-clypeus, as well as the postgenaloccipital area posterior to the ocular margin, are projected.

\section{Cephalic appendages}

Antennae (Figs. 9, 43-45). Clavate and tricarinate, with a median carina from the 4th flagellomere on and two lateral carinae from the 11th flagellomere on, without dimorphic characters and with no observed variation in the number of articles; both sexes with 40 flagellomeres. The length is equal to 5.9 times the width of the eye. The robust scape is flattened dorsoventrally with medianlaterally located bristles characterizing a sensitive region. Pedicel like a ring, about half the size of the scape and with a set of bristles near the inferior margin, similar to those belonging to the scape (Fig. 43).

\section{Mouthparts (Figs. 8, 10-12, 51)}

Labium (Figs. 8, 10-12). Weakly sclerotized structure, the central region of the proboscidial cavity is triangular, laterally limited by the stipes and ventrally by the base of the labial palps and hypostomal bridge. Labial palp is 2.5 times greater than the width of the head, in lateral view. Trisegmented, the basal segment is similar in length, but wider than the distal segment, and presents the Reuter's sensitive spot on its anterior inner face. The medium segment, is the largest of the three. The distal segment is narrower, distally reducing its width.

Maxillae (Figs. 8, 10, 51). On the anterior region of the proboscidial cavity formed by the galea, stipe and cardo. Galea with scales on the apical region (Fig. 51), about 4.3 times bigger than the width of the eye. Stipe on the base of the galea, placed between the labium and the subgenal region. Cardo is reduced in size and subquadrangular in shape.

Cervical Region (Fig. 13). Between the head and thorax, reduced when compared with other regions of the body. Ar- 
Table II. Morphological differences among species in different subfamilies and tribes of Nymphalidae.

\begin{tabular}{|c|c|c|c|c|}
\hline Characters & $\begin{array}{c}\text { Agrias claudina } \\
\text { Charaxinae-Preponini }\end{array}$ & $\begin{array}{c}\text { Memphis moruus } \\
\text { Charaxinae-Anaeini }\end{array}$ & $\begin{array}{c}\text { Actione melanisans } \\
\text { Heliconiinae-Acraeini }\end{array}$ & $\begin{array}{c}\text { Thyridia psidii } \\
\text { Ithomiinae-Mechanitini }\end{array}$ \\
\hline Compound eye & glabrous & glabrous & glabrous & glabrous \\
\hline Number of antenna articles (average) & 60 & 46 & 40 & 43 \\
\hline Fronto-clypeus & subrectangular & trapezoid & subquadrangular & subrectangular \\
\hline Paraocular area from the subgena & continuous & continuous & continuous & narrow \\
\hline Clypeogenal section of the laterofacial suture & $\begin{array}{l}\text { short, without contact with } \\
\text { the laterofacial suture }\end{array}$ & $\begin{array}{l}\text { short, without contact with } \\
\text { the laterofacial suture }\end{array}$ & $\begin{array}{l}\text { elongated toward the } \\
\text { dorsal region, with contact } \\
\text { with the laterofacial suture }\end{array}$ & $\begin{array}{l}\text { contiguous with the } \\
\text { laterofacial suture }\end{array}$ \\
\hline Transclypeal band & presence & presence & presence & presence \\
\hline Basal segment of the labial palp & short & short & elongated & elongated \\
\hline Rudimental maxillary palp & presence & presence & absence & absence \\
\hline Cervical region- articulation with the head & $\begin{array}{l}\text { little elongated compared } \\
\text { to the posterior ventral } \\
\text { expansion }\end{array}$ & $\begin{array}{l}\text { little elongated compared to } \\
\text { the posterior ventral } \\
\text { expansion }\end{array}$ & $\begin{array}{l}\text { similar length compared to } \\
\text { the posterior ventral } \\
\text { expansion }\end{array}$ & $\begin{array}{l}\text { similar length compared } \\
\text { to the posterior ventral } \\
\text { expansion }\end{array}$ \\
\hline Prothoracic leg on males & glabrous & glabrous & with bristles & glabrous \\
\hline Tegula & $\begin{array}{l}\text { without anterior ventral } \\
\text { expansion }\end{array}$ & $\begin{array}{l}\text { without anterior ventral } \\
\text { expansion }\end{array}$ & $\begin{array}{l}\text { without anterior ventral } \\
\text { expansion }\end{array}$ & $\begin{array}{l}\text { without anterior ventral } \\
\text { expansion }\end{array}$ \\
\hline Dorsoanterior margin of the scutellum II & $\begin{array}{l}\text { in the same height of the } \\
\text { postalar plate }\end{array}$ & $\begin{array}{l}\text { posterior to the postalar } \\
\text { plate }\end{array}$ & $\begin{array}{l}\text { anterior to the postalar } \\
\text { plate }\end{array}$ & $\begin{array}{l}\text { in the same height of the } \\
\text { postalar plate }\end{array}$ \\
\hline Dorsoanterior margin of the scutellum III & straight & rounded & angled & straight \\
\hline Furcasterum & without lateral lamellae & with lateral lamellae & without lateral lamellae & with lateral lamellae \\
\hline Discal cell of the hindwing & closed & closed & closed & closed \\
\hline Odoriferous hairpencils on the wing & presence & absence & absence & presence \\
\hline Humeral vein (h) & simple & distally forked & simple & distally forked \\
\hline Curvature of the humeral vein (h) & toward to the apex & $\begin{array}{l}\text { branched, toward to the } \\
\text { basis and the apex }\end{array}$ & toward to the apex & $\begin{array}{l}\text { branched, toward to the } \\
\text { basis and the apex }\end{array}$ \\
\hline Basal cell & absence & absence & absence & absence \\
\hline Sclerotized lobe preceding the tergo-pleural bar & absence & absence & absence & absence \\
\hline Hypandrium & absence & absence & absence & absence \\
\hline Anterior projection of the saccus & short and robust & short and straight & short and robust & short and dorsally curved \\
\hline Gnathos & free & fused & absence & free \\
\hline Aedeagus & anteriorly thin & cylindrical & distally thin & distally thin \\
\hline Shape of the fultura inferior & subtriangular & trapezoid & subtriangular & $\mathrm{V}$ \\
\hline $\begin{array}{l}\text { Distal portion of the anteapophysis external on } \\
\text { the integument }\end{array}$ & absence & absence & absence & absence \\
\hline Signa & presence & presence & absence & absence \\
\hline $\begin{array}{l}\text { Length of the corpus bursae compared to the } \\
\text { ductus bursae }\end{array}$ & smaller & similar & similar & similar \\
\hline Shape of the corpus bursae ventrally & fusiform & rounded & rounded & oval \\
\hline
\end{tabular}

ticulates anteriorly with the head and posteriorly with the propleuron. Cervical organ, located posteroventral to the lateral expansion that articulates with the head, is "cushion" shaped and coated with numerous differentiated bristles.

\section{Thorax}

Prothorax (Figs. 14-16). The smallest of the three thoracic segments and mostly formed by membranous areas. Bilateral patagia prominent in dorsal view, separated dorsally by the anterior region of the pronotum. The pronotum is delimited anteriorly by the patagia, laterally by membranous regions and posteriorly by the prescutum II. In lateral view, the first spiracle is posterodorsal to the episternum I, and ventral to the prealare process II.

In lateral view, the patagia are prominent dorsoanteriorly and the episternum I ventrally. Pronotum is dorsoposterior to the patagia.

The presternum I is anteroventrally subtriangular. In the ventral view of the prothorax, the episternum I occupies the largest area, between the presternum I and the base of the prothoracic legs. Distal ends of the patagia are dorsolateral to the episternum I. Furca I is posterior to the base of the prothoracic coxae, articulating posteriorly with the subtriangular shaped espinasternum I.

Mesothorax (Figs. 14-16). The largest thoracic segment. In dorsal view, the prescutum II is reduced and located anteromedial to scutum II. The prealare process II is a thin sclerotized band lateroanterior to scutum II, which is narrower anteriorly, widening towards the scutellum II. Lateroanteriorly, the scutal suture II separates the scutum II from the suralare II; posteriorly, the scutellum II is separated from the scutum II by the scuto-scutellar suture II.

Laterally, the prescutum II, is anterior to scutum II and dorsal to the prealare process II. The tegular arm is posteroventral to the prealare process II, elongated and shaped as a tilted "C". The tegula, as a movable lobe (Fig. 53, 54), is projected at the height of the tegular arm, displaying a ventral projection to the basalare II and a posterolateral projection 


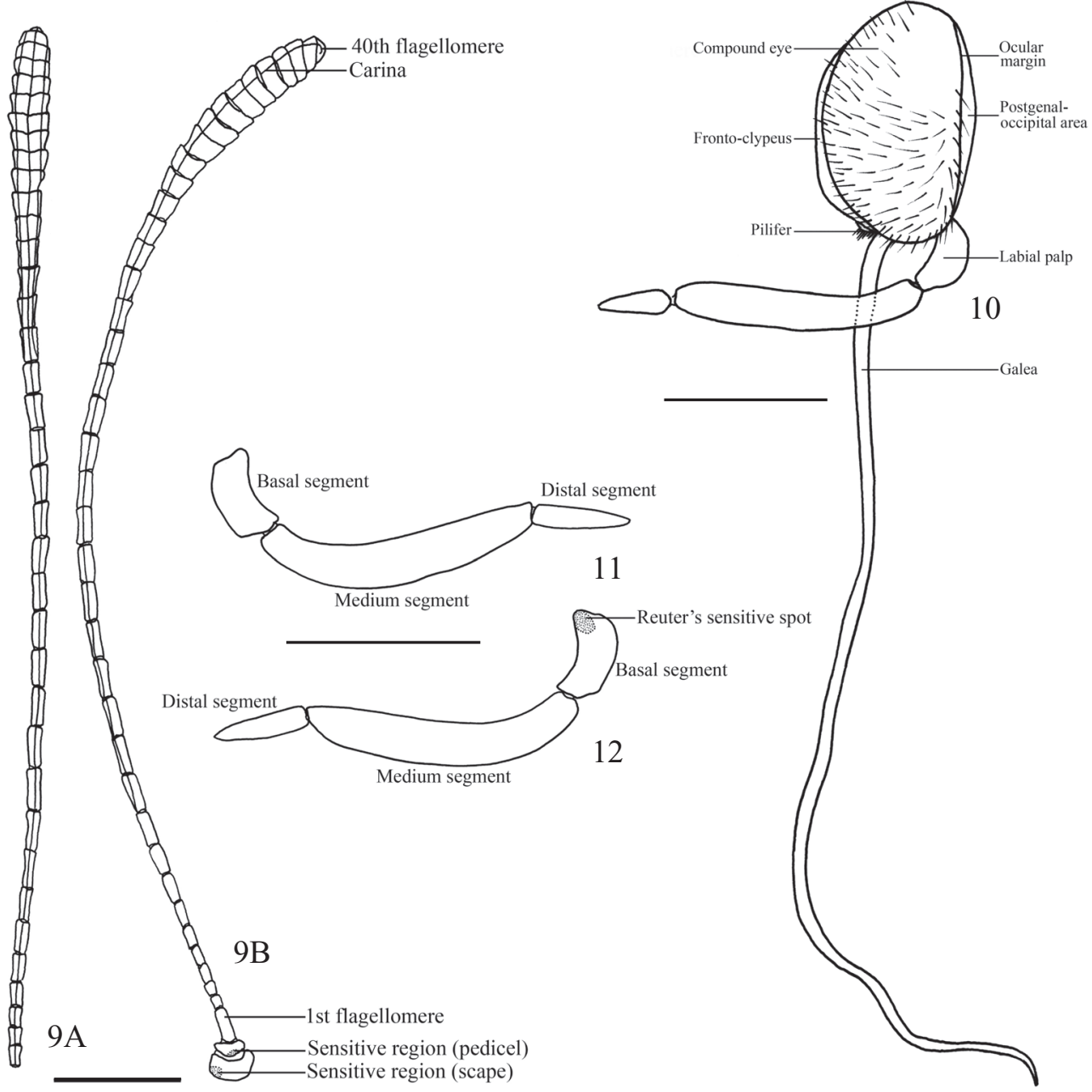

Figs. 9-12. Dynamine postverta postverta-. Head: 9. Antenna: A, inner lateral view; B, external lateral view; 10. Head in lateral view; 11, 12. Labial palp: 11, external lateral view; 12, inner lateral view. Scale bar $1 \mathrm{~mm}$.

that reaches the middle width of the suralare II. The adnotale is located posterodorsal to the subalare II, as a posteroventral expansion of the scutum II. Posterior to the adnotale, the axillary cord II is supported through the lateroanterior extensions of the scutellum II and the postnotum II.

Pleuron is divided into two distinct regions: the proximal anterior episternum II and the distal and posterior epimeron II, separated by the pleural suture II which extends dorsolongitudinally to the coxo-pleural articulation II ventrally. The episternum II is separated into anepisternum II and catepisternum II, located dorsally and ventrally, respectively. Basalare II is oval, located dorsoanterior to the catepisternum II and enveloped posteriorly by the anepisternum II. The preepisternum II is located anterior to the catepisternum II and separated from it by the preepisternal suture II. The posterodorsal region of the epimeron II reaches the ventral margin of the postalar bridge. Posteroventral to the epimeron II, the second thoracic spiracle is located on the intersegmental membrane between the meso and metathorax.

In ventral and anterior view, the preepisternum II is located laterally to espinasternum I. The preepisternal suture II posteriorly separates the preepisternum II from the catepisternum II. The largest of the ventral sclerites of the thorax, the basisternum II is located anteromedially in relation to the mesothoracic coxae and is delimited laterally by anterior twothirds of the catepisternum II and by the posterior third of the epimeron II. The discrimen II extends longitudinally to the furcal pit II, forming an invagination of the sternum II.

Metathorax (Figs. 14-16). The second largest thoracic segment. Dorsally divided into the scutum III anteriorly and scutellum III posteriorly, separated by the scuto-scutellar suture III. Scutum III narrower medially, gradually widening toward the lateral margins, forming two subtriangular shaped areas. While the smaller and triangular shaped scutellum III is located posteriorly.

Laterally, the subrectangular scutum III is separated ventrally from the suralare III by the scutal suture III. The axillary cord III is supported on the lateroanterior extensions of the scutellum III. The posterior notal wing process III appears as a small extension in the posteroventral region of the scutum III. Subalare III is a narrow sclerite located in the center of the pleural membrane. 

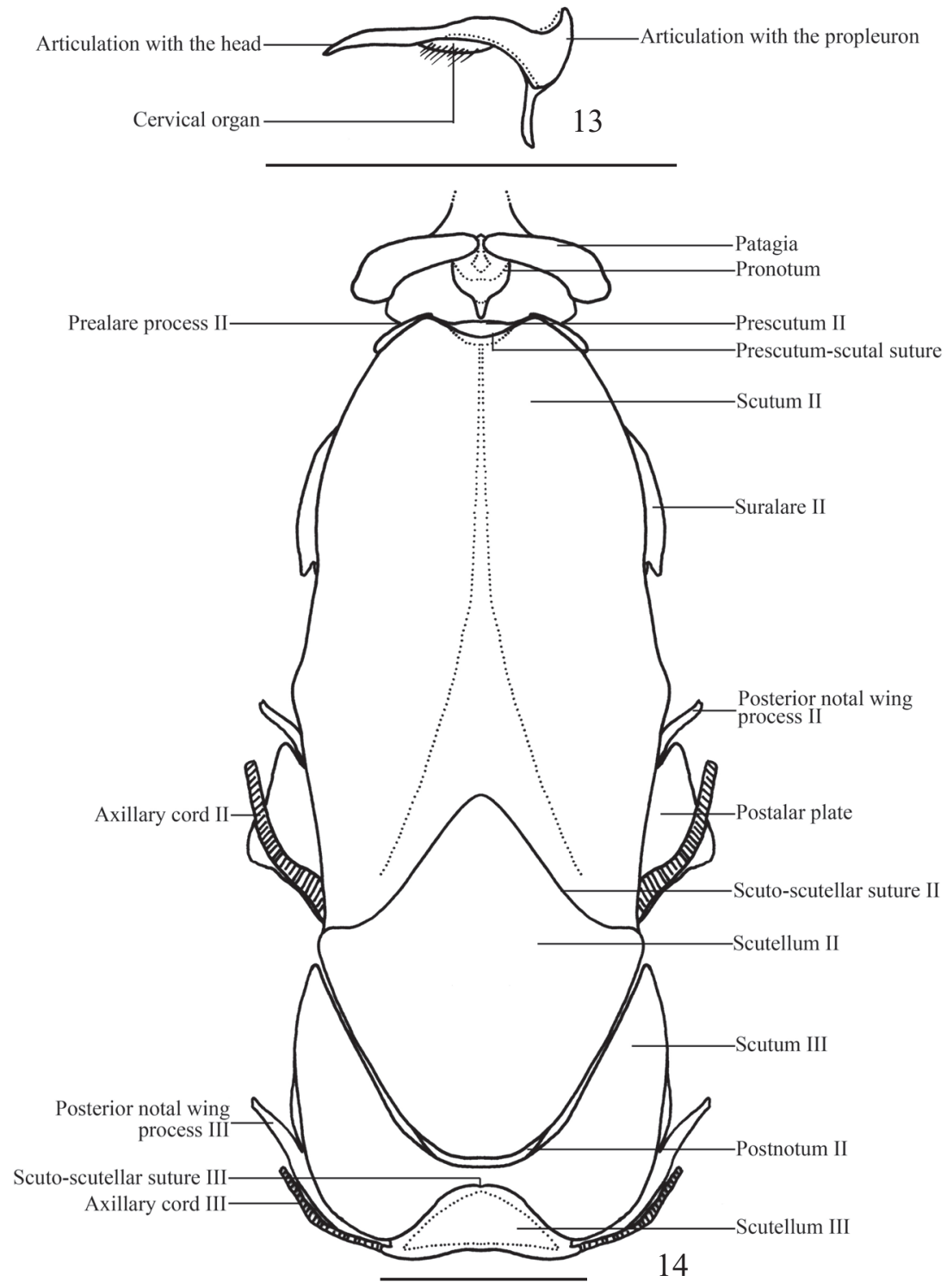

Figs. 13-14. Dynamine postverta postverta. 13. Cervical region in lateral view; 14. Thorax in dorsal view. Scale bar $1 \mathrm{~mm}$.

Pleural region III with a conformation similar to the pleural region II, but without the presence of the preepisternum and the basisternum. Anepisternum III is evident and distinctly separate from the catepisternum III by the anepisternal suture III. Anterodorsal to the catepisternum III, the basalare III is oval, has a superimposed dorsal and lateral structure called the basalare III "pad" (Fig. 58), which is membranous and has numerous bristles dorsally. The epimeron III extends dorsoposteriorly towards the ventral part of the postnotum III.

In ventral view, the discrimen III extends mediolongitudinally from the anteromedial margin of the metathorax to the furcal pit III, posteriorly. The catepisternum III appears as a subrectangular plate anterior to the metathoracic coxae.

\section{Thoracic appendages}

Legs (Figs. 17-23, 55-57). Stunted, relative to the size of the others, the smaller prothoracic leg is sexually dimor- phic; the male tarsus is unisegmented and the female pentasegmented, both without a terminal claw. Coxa I elongated, wider at the basal end and gradually narrowing distally. Trochanter subrectangular, the smallest among the segments of the leg. The prothoracic femur and tibia are elongated and have similar lengths. Tarsus I is composed of five tarsomeres in females, the proximal one being the largest, approximately four times the length of the others that have similar lengths, and they all have spines distally. Males with a single slender tarsus, without spines or bristles.

The meso and metathoracic legs present a similar conformation. Coxa II longitudinally divided into two parts by the coxal suture II, the anterior eucoxa II and the posterior meron II. Coxa III similar to coxa II. Trochanter II subquadrangular and trochanter III subtriangular. Femurs II and III elongated. Meso and metathoracic tibiae covered with bristles, with a pair of spurs which are articulated to the inner distal end. The dis- 


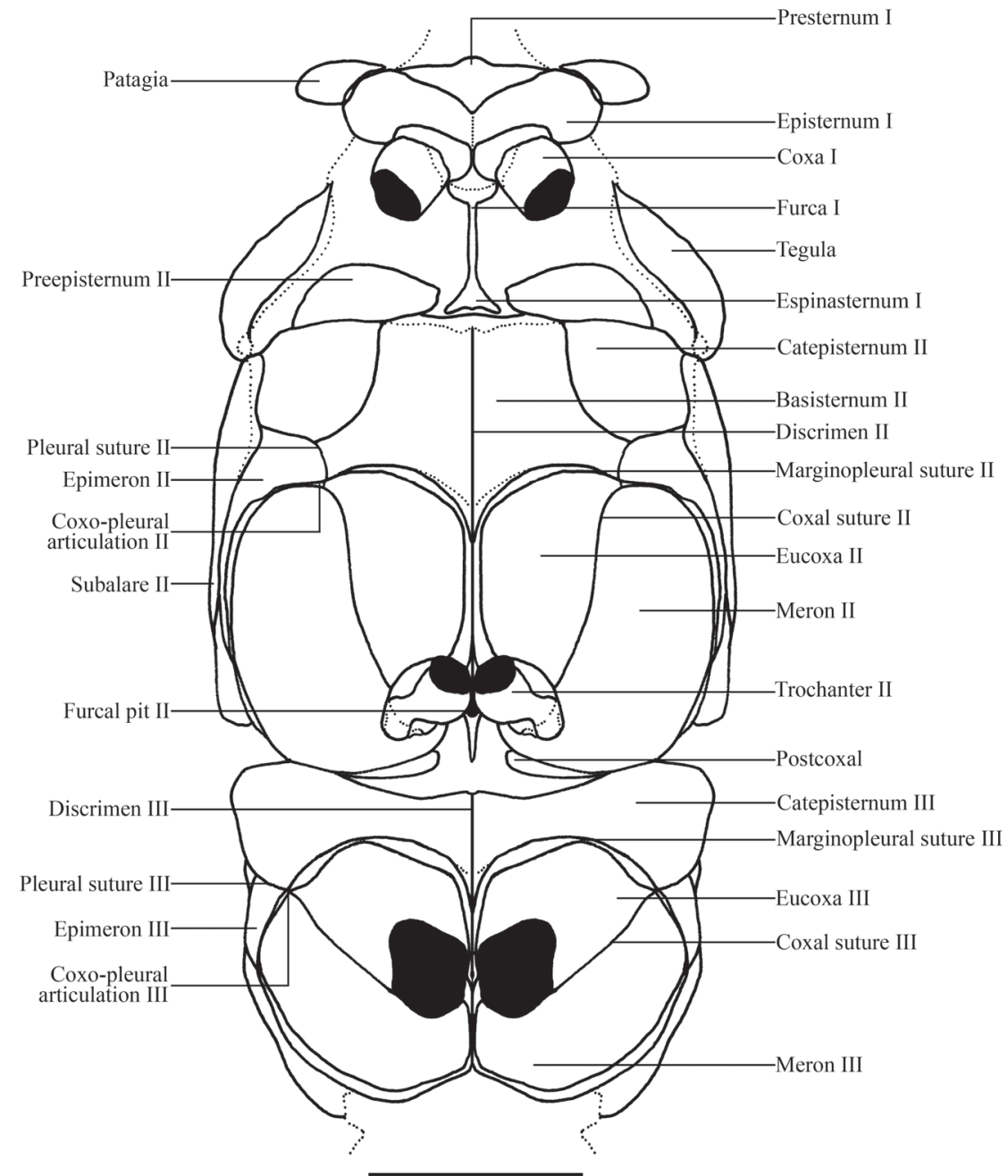

Fig. 15. Dynamine postverta postverta. Thorax in ventral view. Scale bar $1 \mathrm{~mm}$.

tal part of the distitarsus has a projected membranous area provided with tarsal claws, pulvillus, unguitractor plate, and the medially located rounded arolium, in the form of a "pad".

Wings (Figs. 26, 27). Forewings are subtriangular in both sexes. Outer margin convex shaped, and slightly concave at the height of $\mathrm{M}_{3}-\mathrm{Cu} \mathrm{A}_{1}$ in males, female wing shape is slightly more rounded. Thicker at the base, the subcosta $(\mathrm{Sc})$ starts at the axillary region, ending at the middle third of the costal margin. The narrow radial (R), beginning next to and parallel to Sc, upon reaching the distal third of the discal cell forks into $R_{1}$ and $R_{S}$, the latter being divided into $R_{2}, R_{3}, R_{4}$ and $R_{5}$, with $R_{2}$ ending before the apex of the wing, $\mathrm{R}_{3}$ and $\mathrm{R}_{4}$ at the apex, and $\mathrm{R}_{5}$ on outer margin. In males, the proximal third of $\mathrm{R}_{1}$ is strongly curved toward Sc, while in females remains parallel. The discal cell is closed. The dci, largest of the transverse veins and with a more pronounced concavity in males, is well defined. The des is only present in females. $M_{1}$ and $M_{2}$ begin separately from the upper apex of the discal cell, while $M_{3}$ begins separately from the previous at the lower apex of the discal cell next to the distal end of dci. In males, $M_{3}$ curves towards $M_{2}$ at its anterior half, a feature not very evident in females. $\mathrm{CuA}_{1}$ and $\mathrm{CuA}_{2}$ begin separately from the discal cell for an equal distance in both sexes, with $\mathrm{CuA}_{1}$ originating near the base of $\mathrm{M}_{3}$ and $\mathrm{CuA}_{2}$ initiating from the distal third of the cubital vein. Vein $2 \mathrm{~A}$, the only anal one, begins from the axillary region, separated from the discal cell up to the anal angle of the wing, closer to the inner margin in females and more distant in males.

Hindwings are convex along the outer margin and appear straight along the costal and inner margins. Vein $\mathrm{Sc}+\mathrm{R}_{1}$ goes from the axillary region to the apex of the wing. The humeral vein (h) curves toward the proximal region of the costal margin, arising from the separation of $\mathrm{Sc}+\mathrm{R}_{1}$ and $\mathrm{R}_{\mathrm{S}}$. Discal cell closed; dci similar to the forewing in males and slightly concave along the inferior third in females. $\mathrm{M}_{1}, \mathrm{M}_{2}, \mathrm{M}_{3}, \mathrm{CuA}_{1}$ and $\mathrm{CuA}_{2}$ similar in conformation as in the forewing, with $\mathrm{M}_{3}$ closer to $\mathrm{M}_{2}$ at its basal half in females, as well as the bases of $\mathrm{CuA}_{1}$ and $\mathrm{CuA}_{2}$ being closer to each other with respect to the males. Anal veins are separated from the discal cell at their bases. 2A ending at the anal angle of wing with a straight appearance in males and slightly curved toward the inner margin in females. In males, $3 \mathrm{~A}$ ends at the posterior third of the anal margin and in the middle in females. 


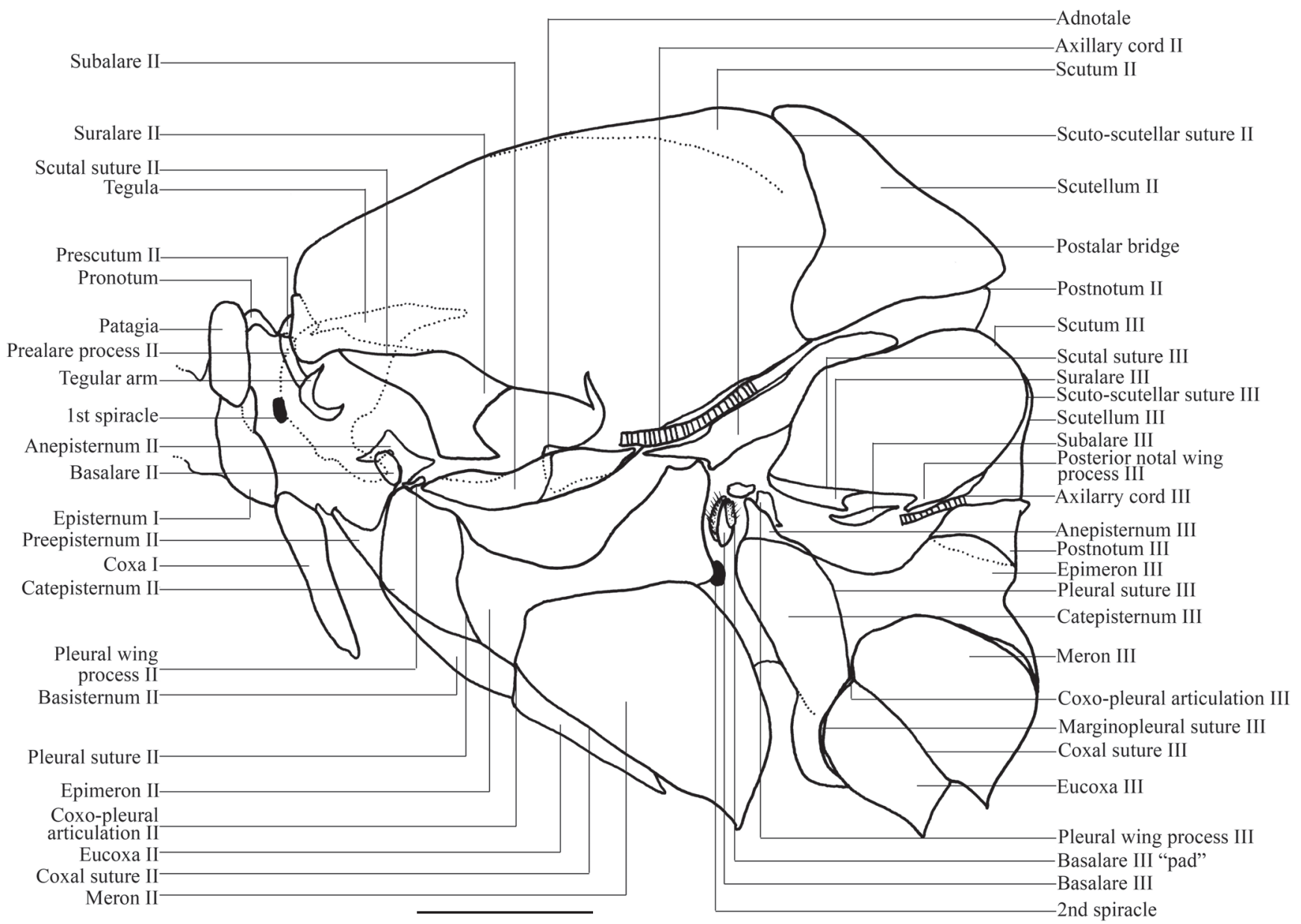

Fig. 16. Dynamine postverta postverta. Thorax in lateral view. Scale bar $1 \mathrm{~mm}$.

\section{Abdomen}

Pregenital structures (Figs. 28-31, 59). The pregenital segments, composed of a sclerotized tergum and sternum, are connected by a membranous pleura with an elliptical spiracle (Fig. 59) on segments $1-7$, respectively. When compared to the male, the female abdomen is wider dorsoventrally.

Tergum I with a membranous anterior third and the rest sclerotized. In side view, tergum I is subrectangular in males and rounded in females. Ventral to tergum I, the tergopleural bar appears as a sclerotized band which is narrow in males and posteriorly widened in females. The anteriorly located prespiracular bar is narrow in both sexes, with a globular sclerotized structure covered with numerous bristles on its dorsal surface. Anterior to spiracle I, the slender sternum I is projected anteriorly toward the anteromedial region of the abdomen and posteriorly articulated to the anterior edge of sternum II. In males, spiracle I is near the posteroinferior margin of the prespiracular bar, whereas in females is larger and located between the pre and postspiracular bars. In ventral view, there is a marked difference between the sexes in relation to the shape and size of abdominal sterna (Figs. 30 and 31).

Male genitalia (Figs. 28, 30, 32-40, 60). As a sclerotized modification of sternum VIII, the hypandrium has a wider proximal region which is located beneath sternum VII, is distally elongated with a forked posterior end, and numerous bristles are distributed over its length (Fig. 60).

The tegumen is posteriorly connected to the uncus, the latter being slender with distal end curved ventrally in the shape of a claw. The angular appendix, which has the shape of a sclerotized lobe, is on the basal part of the ventral projection of the tegumen. The gnathos, which are articulated on the medianventral margin of the tegumen through a narrow membrane, are projected ventrally and attached medianposteriorly. The fultura inferior, a ventrally located narrow sclerotized "Y" shaped structure which provides support for the aedeagus, is visible posteriorly.

The arm of the saccus is projected dorsally as a thin sclerotized band that reaches the ventral projection of the tegumen, forming an arch. The anterior projection of the saccus is elongated with a length slightly smaller than the aedeagus.

Mediolaterally flattened valvae, forming a pair of plates articulated on the lower half of the dorsal arm of the saccus; posterior edge with numerous bristles distributed along the inferior edge of the valvae.

Aedeagus cylindrical; bulbus ejaculatorius located anteriorly; and distal vesica without a cornutus. 


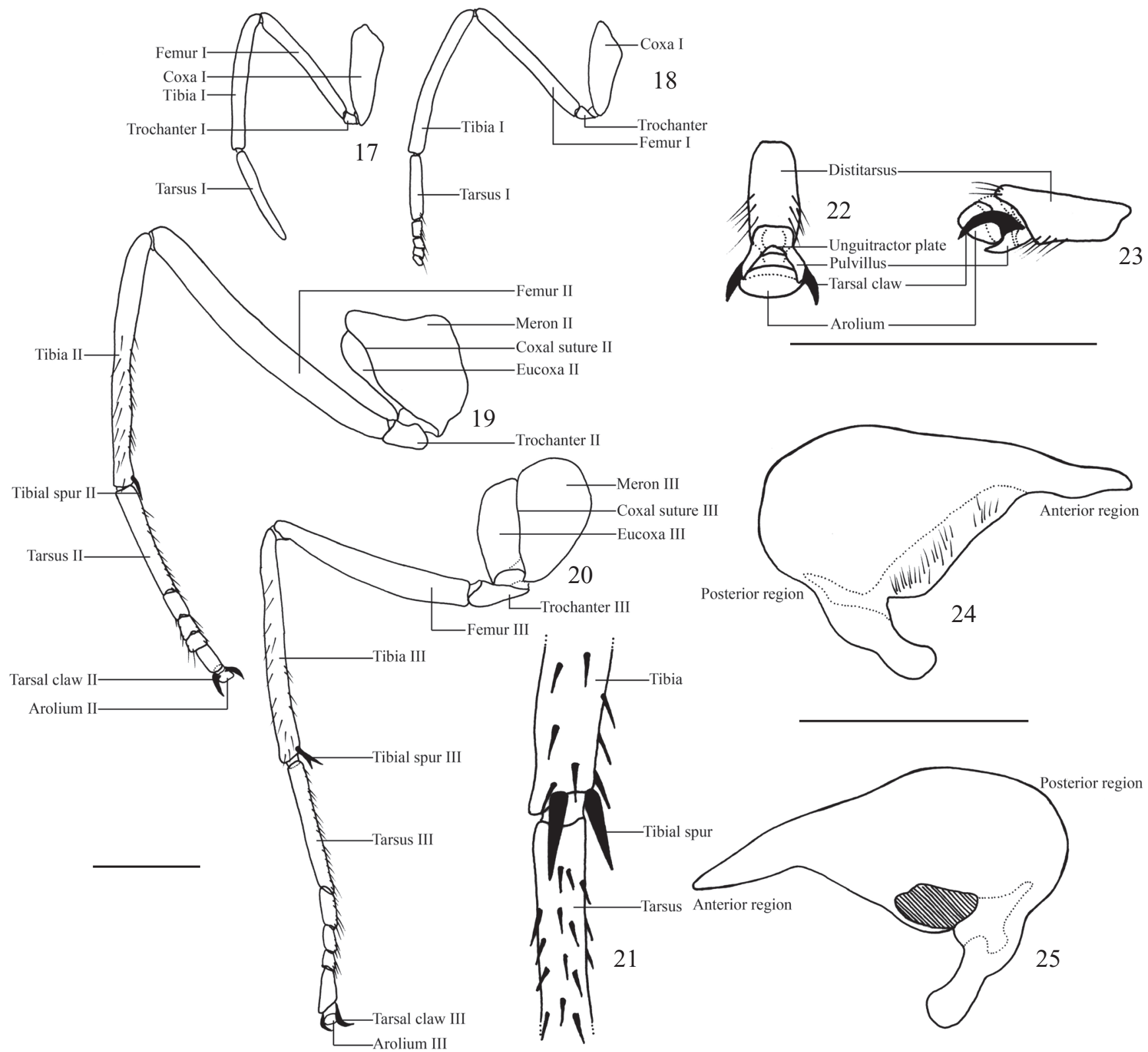

Figs. 17-25. Dynamine postverta postverta. Legs: 17, 18. Prothoracic legs: 17, male; 18, female; 19. Mesothoracic leg; 20 . Metathoracic leg.; $21,23$. Mesothoracic leg: 21. Detail of the tibial spur region; 22, 23. Detail of the distitarsus and terminal claw: 22, ventral view; 23, lateral view; 24, 25. Tegula: 24, external lateral view; 25 , inner lateral view. Scale bar $1 \mathrm{~mm}$.

Female genitalia (Figs. 29, 31, 41, 42). Modification of the eighth, ninth and tenth abdominal segments. Tergum VIII with anteapophyses as anteroventral projections on both sides, which are prominent on the external face of the abdominal integument. Papilla analis located posteromedially, with little sclerotization and numerous bristles distributed on the surface. Postapophyses as a pair of projections internal to the integument, anteromedially to the papilla analis, curved dorsally and about a third of the length of the anterior apophyses.

Sternum VIII represented bilaterally by the lamella antivaginalis, as two subtriangular sclerotized invaginations. Ostium bursae with a posteromedian opening into the lamella antivaginalis. Lamella postvaginalis is absent.
Bursa copulatrix formed by the ostium, ductus and corpus bursae. Corpus bursae is saculiform, without signa and similar in length to the ductus.

\section{DISCUSSION}

This study reinforces the importance of understanding the external morphology due to the differences observed between species (Tables I and II), sometimes within the same subfamily, which makes them extremely necessary for the taxonomy of the groups. However, there are only a small number of studies of this nature in comparison with the existing immense and diverse fauna, possibly due to the short- 


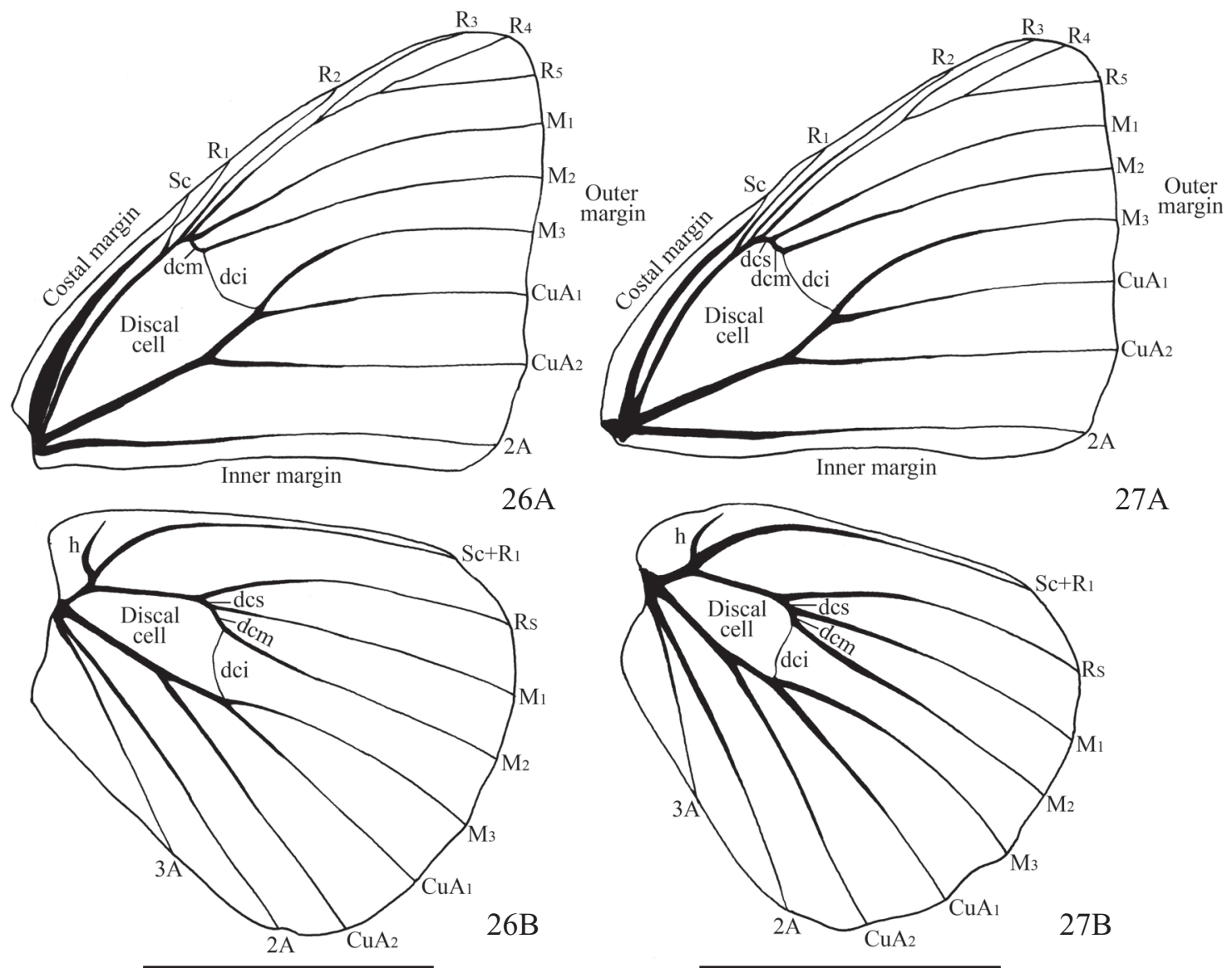

Figs. 26-27. Dynamine postverta postverta. Wings: 26. Male: A, forewing; B, hindwing; 27. Female; A, forewing; B, hindwing. Scale bar 1cm.

age of specialized scholars, notwithstanding the difficulty in the preparation and observation of the sclerites and sutures, due to the scales.

The presence of setae surrounding the compound eyes is one of the unique features of Dynamine postverta postverta with respect to the other Nymphalidae compared in this work, which have glabrous eyes (Tables I and II). However, the absence of more comprehensive studies involving the external morphology within the Biblidinae does not make it clear how this feature behaves in other taxa belonging to the subfamily.

Anepisternum II and III dorsal to the catepisternum II and III respectively, separated from them by the anepisternal sutures in each segment; this conformation is more evident in the metathorax. Located anteriorly to these, the basalare II and III which are oval in both segments, with the metathoracic being supported by a membranous bristle covered structure called the basalare III "pad" (Figs. 16 and 58) is observed, which is similar in conformation to other external morphology studies of other families of butterflies such as Lycaenidae: Glaucopsyche lygdamus (Doubleday, 1841) (Sorensen 1980); Hemiargus hanno (Stoll, 1790) (Duarte 2007) and Papilionidae: Heraclides anchisiades capys (Hübner, [1809]) (Leite et al. 2010b). The other studies of the external morphology of Nymphalidae treat the anepisternum and basalar sclerites in an opposite position, and do not mention the presence of the basalare III "pad", either due to its absence or to observation error. It is believed that further research should involve these structures. However, by the definition of these sclerites (sensu Torre-Bueno 1989), it is believed that the conformation seen in Dynamine postverta postverta is adequate.

The hypandrium (Figs. 40 and 60) represents a strongly sclerotized structure located anteroventrally to the male genitalia, as a modification of the eighth sternum.

The current study confirms the presence of such a structure in Dynamine postverta postverta and the absence in the other Nymphalidae here compared, which somewhat corroborates previous studies that treat the hypandrium as a character which supports the monophyly of the subfamily Biblidinae (Jenkins 1990; Harvey 1991; Freitas \& Brown Jr. 2004). This structure is extremely diversified among the previously observed species within Biblidinae, including large modifications within the many genera which have already been discussed in reviews (Jenkins 1983, 1984, 1985a,b, 1986, $1987,1989,1990)$, making this sclerite one of great importance for systematic studies of genera and tribes of Biblidinae. The above mentioned works deal with the hypandrium as part of the genitalia, which someway follows that proposed by Klots (1956), where the formation of the genitalia may occur from the eighth abdominal segment, however, with lim- 

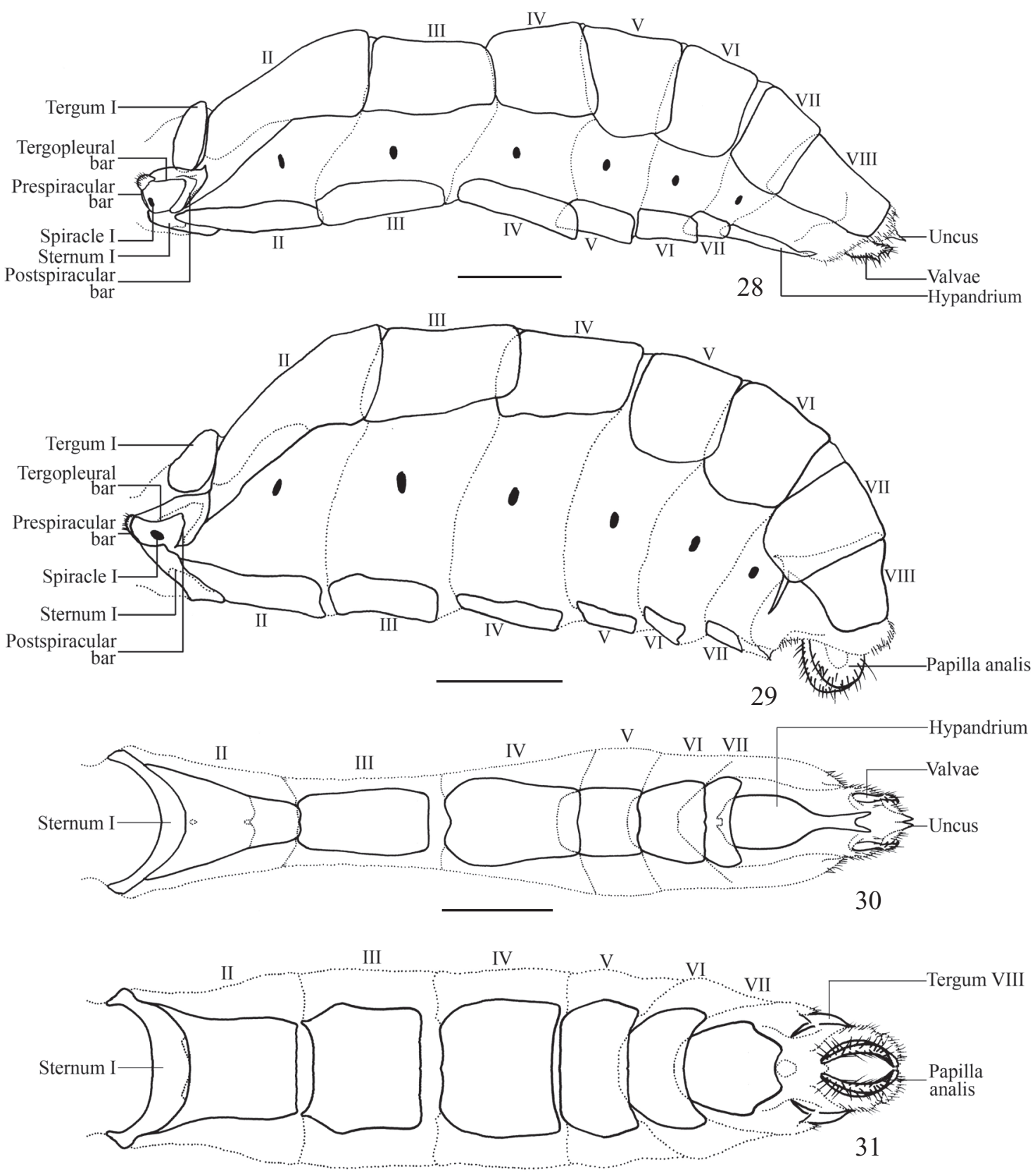

Figs. 28-31. Dynamine postverta postverta. Abdomen and pregenital segments: 28 and 30. Male: 28. lateral view; 30 , ventral view; 29 and 31. Female: 29, lateral view; 31, ventral view. Scale bar $1 \mathrm{~mm}$.

ited cases of modifications in this segment such as the superuncus, common in Papilionidae (Srivastava 1965; Miller 1987; Leite et al. 2011). Some papers deal with the hypandrium as abdominal plate (Pierce 1914; Niculescu 1978) or subgenital plate (Klots 1956). In some cases, this structure may even present lateral or lateroventral posterior projections which often exceed the length of the valvae, being called "rami" (Niculescu 1978). Such projection is clearly seen in Hamadryas Hübner, [1806] and Catonephele Hübner, [1819] (Jenkins 1983, 1985a), being absent in D. postverta postverta. In Riodinidae, the eighth sternum of the males is figured in several studies dealing with the systematics of the tribe Nymphidiini, but it does not receive the name of hypandrium (Hall 1999; Hall \& Harvey 2002). According to Pierce (1914), the presence of a similar sternite occurs in some Geometridae from South America, as well as in Pyralidae. However, the presence of a hypandrium in other groups outside Biblidinae deserves further study.

In the female genitalia about two-thirds of the distal part of the anteapophysis is located on the external surface of the abdomen (Figs. 41 and 42). Up to now, such a feature, seems unique to the genus Dynamine, as observed in Dynamine chiquita Willmott \& Hall, 2010 (Willmott \& Hall 2010). The other species of Nymphalidae compared in this study did not 

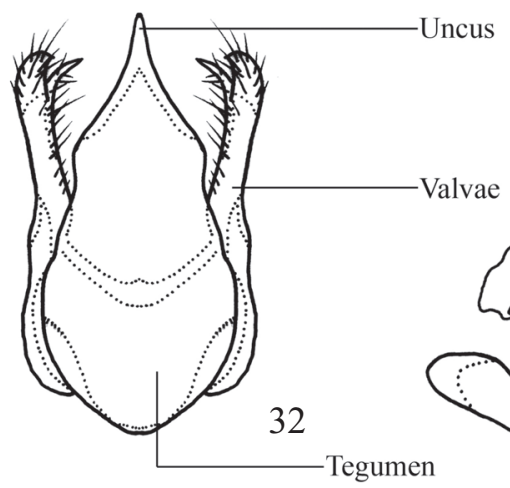

Angular appendix
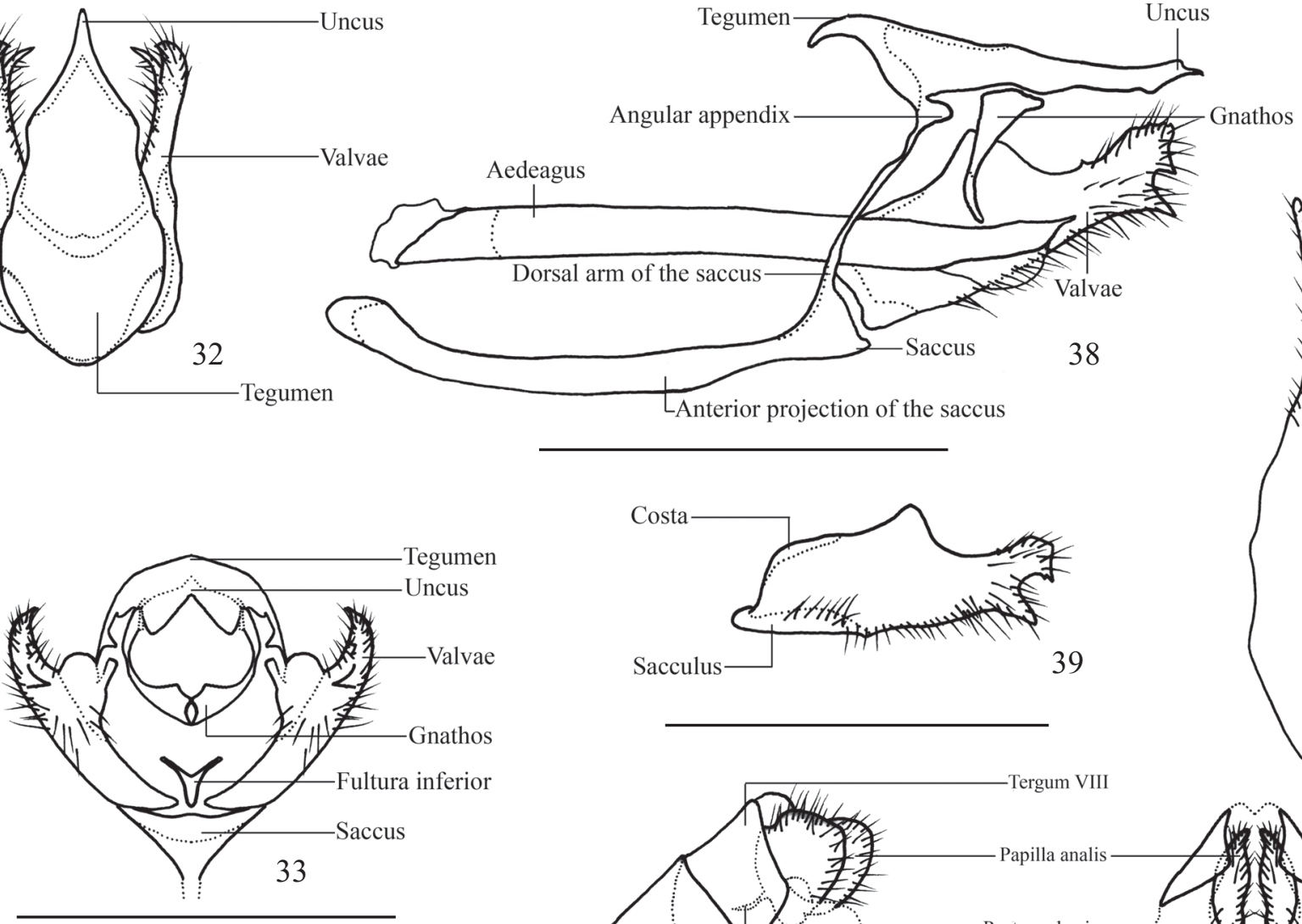

Valvae

38

Anterior projection of the saccus

Bulbus ejaculatorius
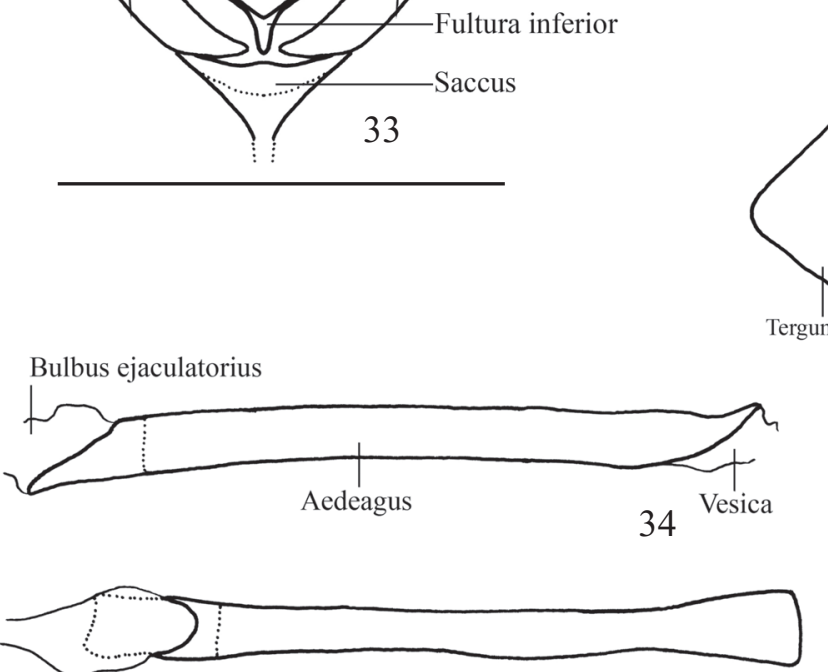

35

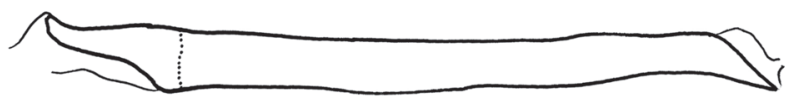

36
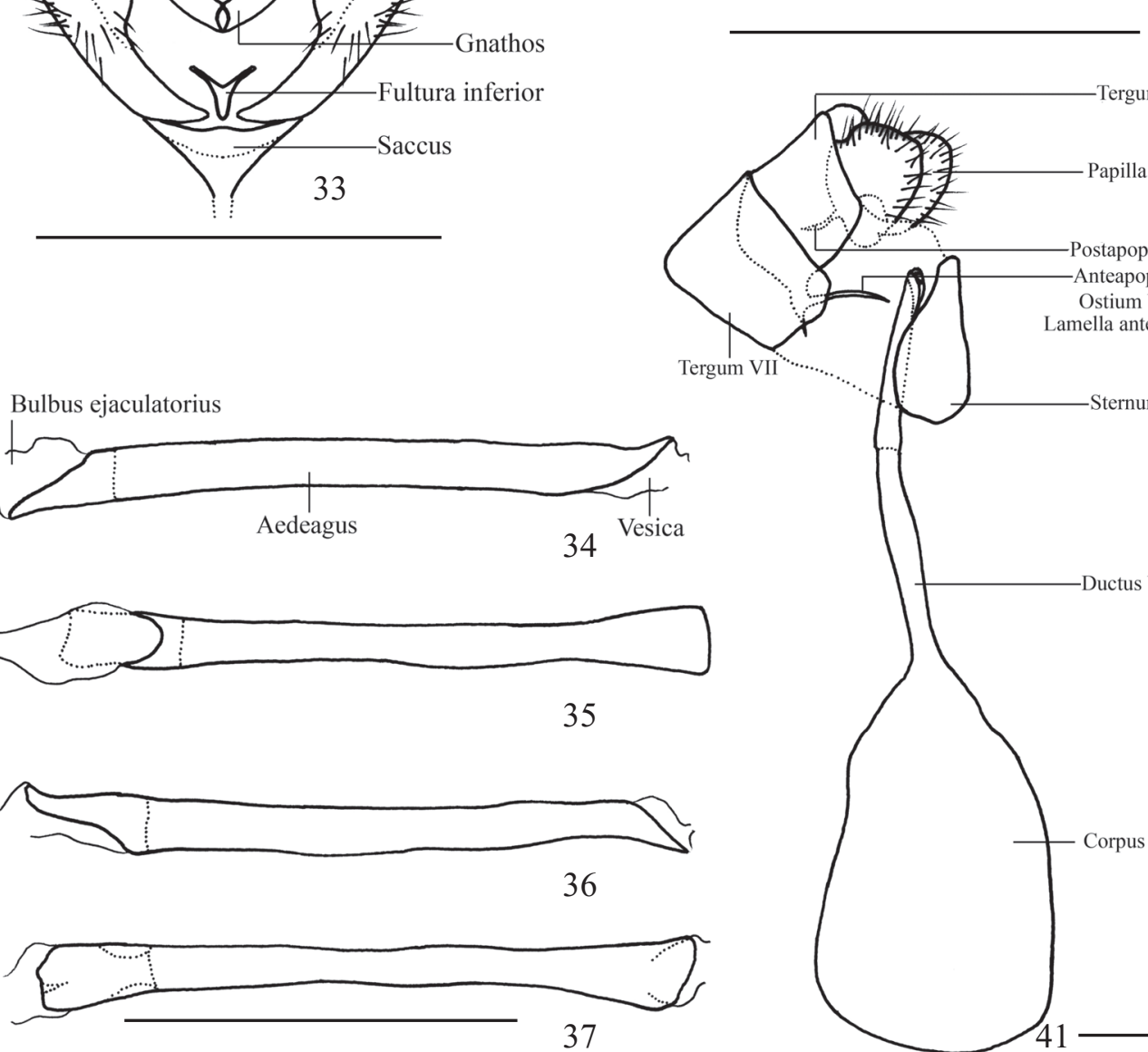

39
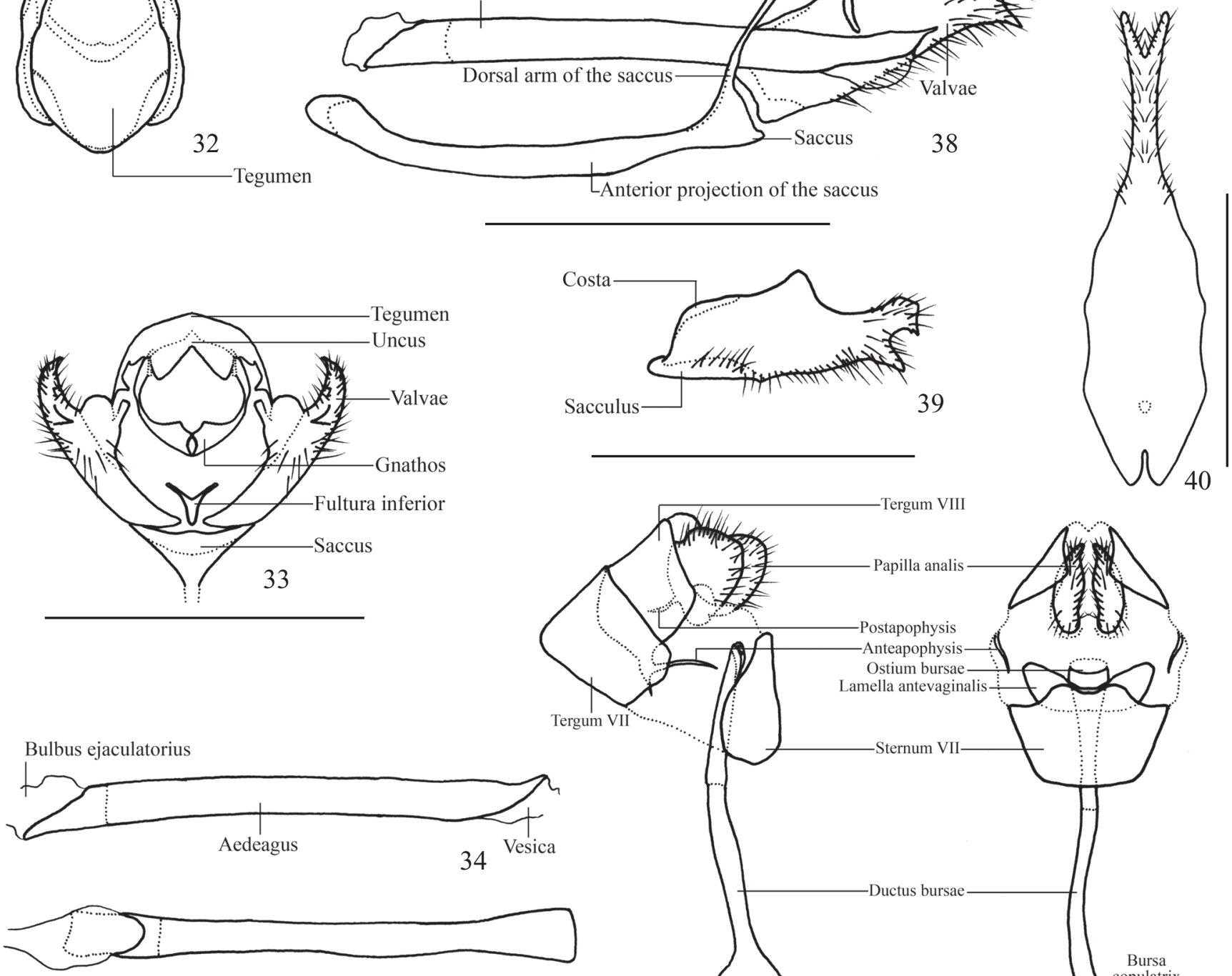

Figs. 32-42. Dynamine postverta postverta. 32-40, Male's genitalia: 32, dorsal view; 33, posterior view; 34-37. Aedeagus: 34, left lateral view; 35 , dorsal view; 36 , right lateral view; 37 , ventral view. 38, lateral view of the genitalia; 39, valvae; 40, hypandrium; 41-42 Female's genitalia: 40, lateral view; 41, ventral view. Scale bar $1 \mathrm{~mm}$.

have this characteristic and this character was not reported in other Biblidinae where the female genitalia have been figured (Jenkins 1983, 1984, 1985a,b, 1986, 1987, 1989, 1990). The absence of signa within the body of the bursa copulatrix of D. postverta postverta is shared with the Acraeini and Mechanitini (Bizarro et al. 2003c; Paluch et al. 2008). However, in other individuals of Biblidinae the signa are present (Jenkins 1983, 1987), as well as in other tribes of 

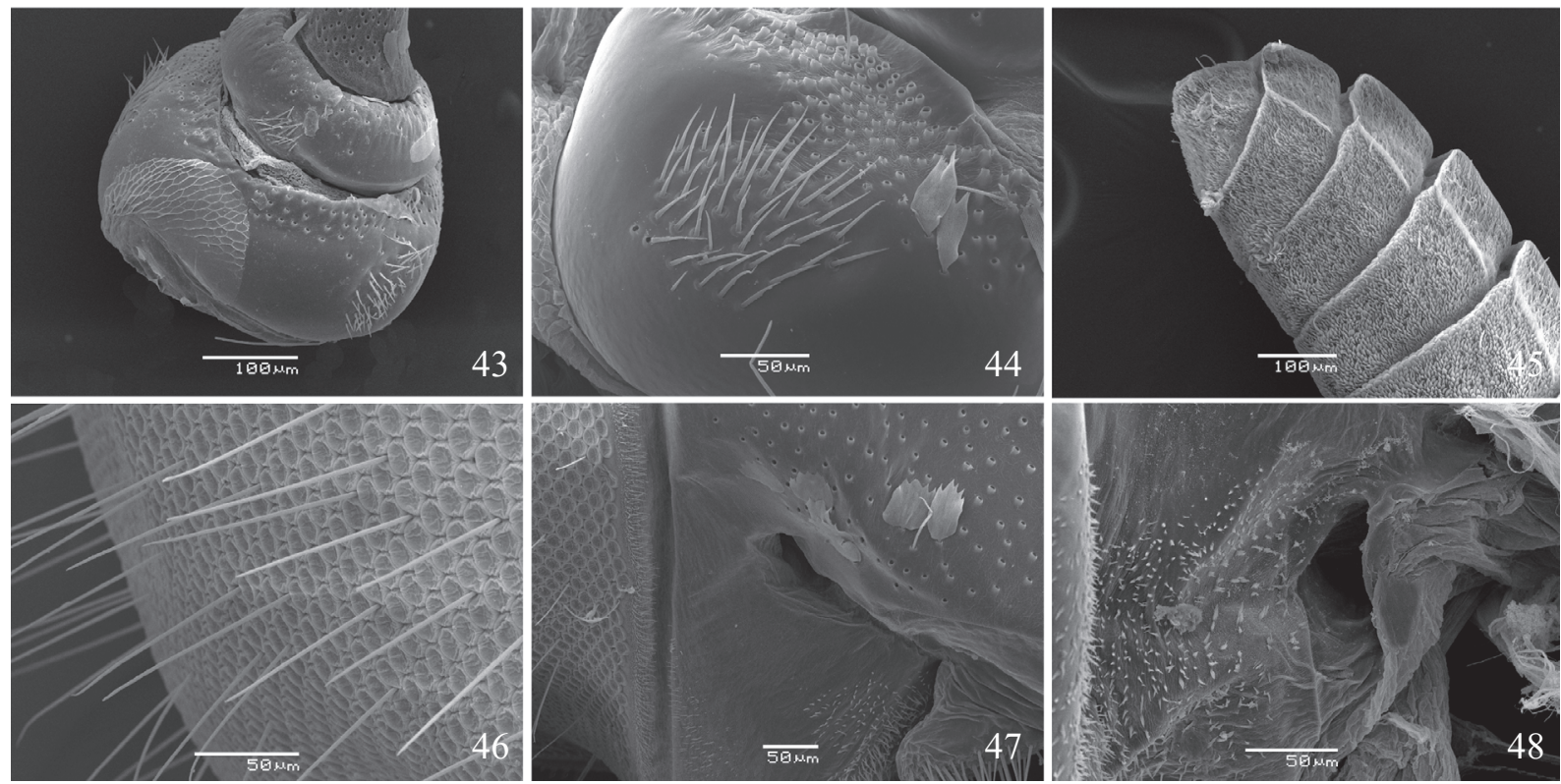

Figs. 43-48. Dynamine postverta postverta. Head: 43, scape and pedicel; 44, detail of the sensitive region on scape; 45, distal portion of the antenna; 46, detail of the bristles of the compound eye; 47 , anterior tentorial pit; 48 , posterior tentorial pit.
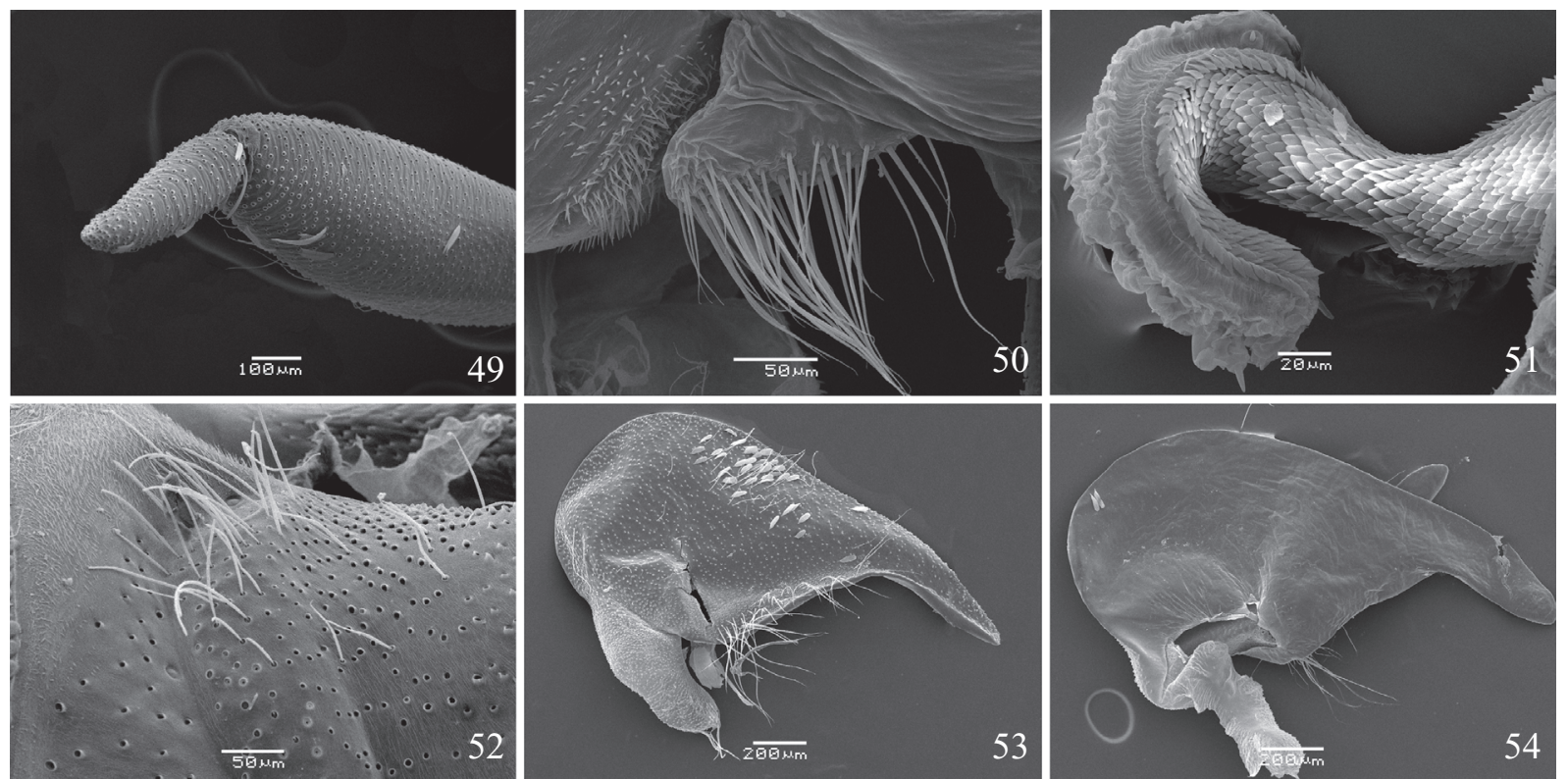

Figs. 49-54. Dynamine postverta postverta. 49-52. Head: 49, distal and median segments of the labial palp; 50, labrum and pilifer; 51, distal portion of the galea; 52, chaetosema; 47-54. Tegula. 53, anterior lateral view; 54, posterior lateral view.

Nymphalidae compared herein (Tables I and II). This character, as well as the length and shape of the bursa seems to vary greatly among the various subfamilies and tribes of Nymphalidae, appearing to be important for the separation of lower level taxa.

The tribes Morphini and Brassolini (Casagrande 1979a,b,c; Bilotta 1992, 1994a,b) present the largest number of characters shared among themselves, with respect to the other individuals observed, followed by the tribes Preponini and Anaeini (Mielke et al. 2004a,b,c; Dias et al.
2010). Charaxinae and Morphinae as a whole presented a large number of morphological similarities between their tribes when compared with other taxa, which in someway places them within a group already found in previous studies (Freitas \& Brown Jr. 2004).

Danaini and Mechanitini (Ehrlich 1958; Bizarro et al. 2003a,b,c) show many similarities with respect to characters, particularly of the head and thorax. The proximity of these tribes has been noted by Brower (2000) and Freitas \& Brown Jr. (2004), with their respective subfamilies being 

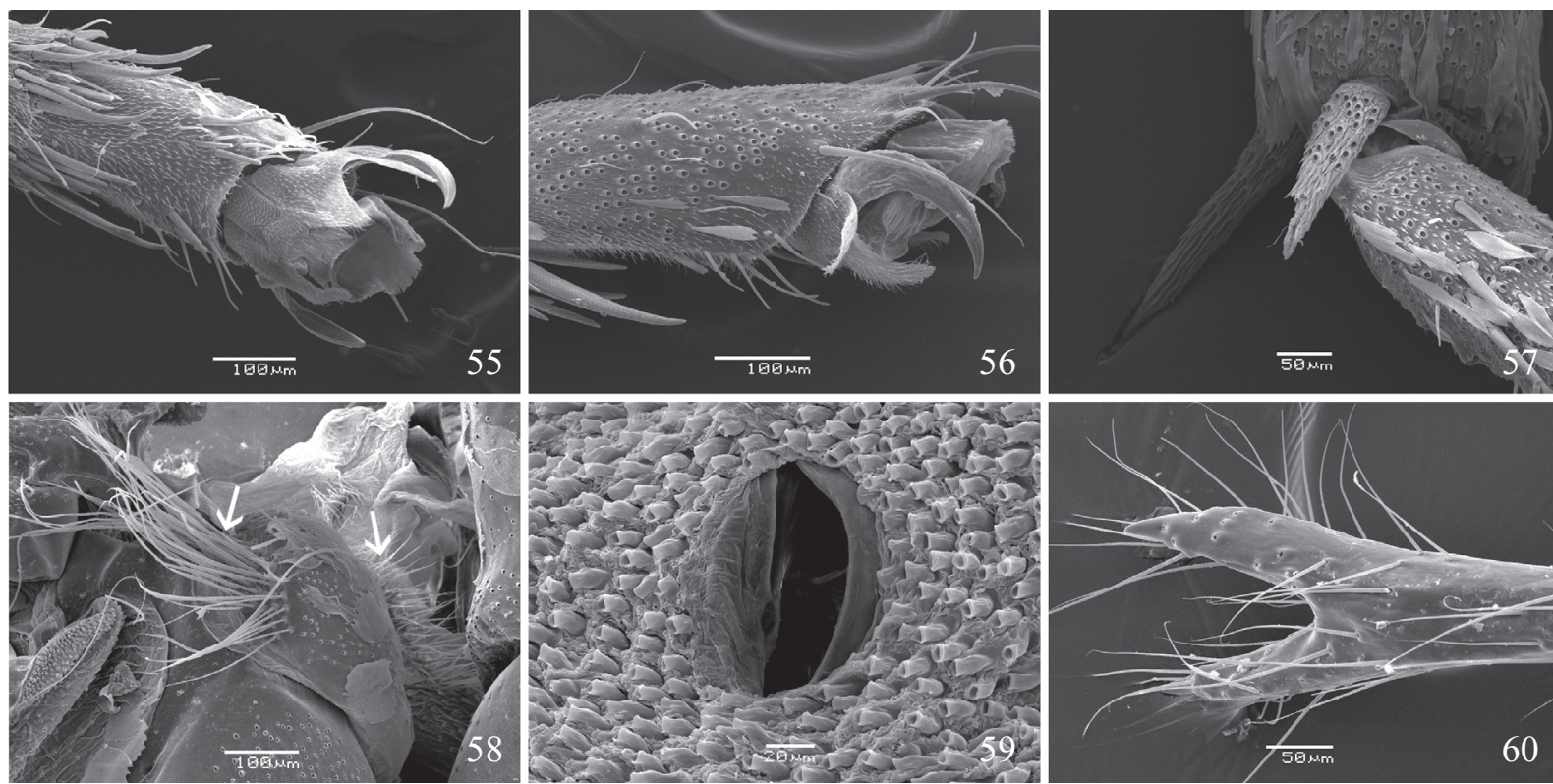

Figs. 55-60. Dynamine postverta postverta. 55-57. Mesothoracic leg: 55, ventral view of the distitarsus and terminal claw; 56, lateral view of the distitarsus and terminal claw; 57, tibial spur region; 58. Basalare III with indication of the "pad" with bristles; 59. Abdominal spiracle; 60. Distal portion of the hypandrium in ventral view.

regarded as sister groups. This study also presents a sharing of characters of the thorax and abdomen between the Acraeini and Mechanitini (Bizarro et al. 2003c; Paluch et al. 2008), considered as distinct groups (Brower 2000; Freitas Jr. \& Brown 2004), which leads us to believe that the characters presented in this study for these individuals may be, somehow, not relevant to the determination of their systematic relationships.

Biblidini have more similarities with the tribes of Charaxinae and Morphinae by the presence of a greater number of characters in common, when compared to the other taxa. However, the low volume of sampled data, as well as the lack of more morphological detailing of the other subfamilies and tribes of Nymphalidae, does not allow a more profound analysis of relationships involving the entire adult morphology.

\section{ACKNOWLEDGEMENTS}

To the Center of Electronic Microscopy (CME) of the Universidade Federal do Paraná (UFPR) for preparing the images. To CNPq (National Council for Scientific and Technological Development) for financial support.

\section{REFERENCES}

Bilotta, I. 1992. Morfologia comparada da cabeça das espécies sulbrasileiras de Morphinae (Lepidoptera, Nymphalidae). Revista Brasileira de Zoologia 9: 261-271.

Bilotta, I. 1994a. Morfologia comparada do tórax das espécies sulbrasileiras de Morphinae (Lepidoptera, Nymphalidae). Revista Brasileira de Zoologia 11: 691-713.

Bilotta, I. 1994b. Morfologia comparada do abdome das espécies sulbrasileiras de Morphinae (Lepidoptera, Nymphalidae). Revista Brasileira de Zoologia 11: 737-748.
Bizarro, J.M.S., Casagrande, M.M. \& Mielke, O.H.H. 2003a. Morfologia externa de Thyridia psidii cetoides (Rosemberg \& Talbot). I. Cabeça e apêndices (Lepidoptera, Nymphalidae, Ithomiinae). Revista Brasileira de Zoologia 20: 279-284.

Bizarro, J.M.S., Casagrande, M.M. \& Mielke, O.H.H. 2003b. Morfologia externa de Thyridia psidii cetoides (Rosemberg \& Talbot) (Lepidoptera, Nymphalidae, Ithomiinae). II. Tórax e apêndices. Revista Brasileira de Zoologia 20: 419-425.

Bizarro, J.M.S., Casagrande, M.M. \& Mielke, O.H.H. 2003c. Morfologia externa de Thyridia psidii cetoides (Rosenberg \& Talbot) (Lepidoptera, Nymphalidae, Ithomiinae). III. Abdome e apêndices. Revista Brasileira de Zoologia 20: 681-684.

Brévignon, C. 2008. Notes sur Biblidinae, les Apaturinae et les Nymphalinae de Guyane Française (Lepidoptera: Nymphalidae). Lambillionea 108: 3-13.

Brower, A.V.Z. 2000. Phylogenetic relationships among the Nymphalidae (Lepidoptera), inferred from partial sequences of the wingless gene. Proceedings of the Royal Society B 267: 1201-1211.

Casagrande, M.M. 1979a. Sobre Caligo beltrao (Illiger). II Morfologia externa da cabeça do adulto (Lepidóptera, Satyridae, Brassolinae). Revista Brasileira de Biologia 39: 223-227.

Casagrande, M.M. 1979b. Sobre Caligo beltrao (Illiger). III Morfologia externa do adulto - tórax. (Lepidoptera, Satyridae, Brassolinae). Revista Brasileira de Biologia 39: 347-355.

Casagrande, M.M. 1979c. Sobre Caligo beltrao (Illiger). IV Morfologia externa do adulto - abdome (Lepidoptera, Satyridae, Brassolinae). Revista Brasileira de Biologia 39: 711-716.

DeVries, P.J. 1987. The Butterflies of Costa Rica and their natural history: Papilionidae, Pieridae, and Nymphalidae. New Jersey, Princeton University Press, $327 \mathrm{p}$.

Dias, F.M.S., Casagrande, M.M. \& Mielke, O.H.H. 2010. Morfologia do exoesqueleto de adultos de Memphis moruus stheno (Pritwittz) (Lepidoptera, Nymphalidae, Charaxinae). Revista Brasileira de Entomologia 54: 376-398

Duarte, M. 2007. Morfologia externa do adulto de Hemiargus hanno (Stoll) (Lepidoptera, Lycaenidae, Polyommatinae, Polymmatini) II. Região cervical, tórax e abdome. Iheringia, Série Zoologia 97: 194-206.

Ehrlich, P.R. 1958. The integumental anatomy of the monarch butterfly Danaus plexippus L. (Lepidoptera: Danaidae). University of Kansas Science Bulletin 38: 1315-1349. 
Freitas, A.V.L. \& Brown, K.S., Jr. 2004. Phylogeny of the Nymphalidae (Lepidoptera). Systematic Biology 53: 363-383.

Hall, J.P.W. 1999. A revision of the genus Theope: its systematics and biology (Lepidoptera: Riondinidae: Nymphidiini). Gainesville, Scientific Publishers, vii+127 p.

Hall, J.P.W. \& Harvey, D.J. 2002. Basal subtribes of the Nymphidiini (Lepidoptera: Riodinidae): phylogeny and myrmecophily. Cladistics 18: 539-569.

Harvey, D.J. 1991. Higher classification of the Nymphalidae, p. 255-273 Appendix B. In: Nijhout, H.F. (ed.). The Development and Evolution of Butterfly Wing Pattern. Washington DC, Smithsonian Institution Press, xiii +297 p.

Iserhard, C.A. \& Romanowski, H.P. 2004. Lista de espécies de borboletas (Lepidoptera, Papilionoidea e Hesperioidea) da região do vale do rio Maquiné, Rio Grande do Sul, Brasil. Revista Brasileira de Zoologia 21: 649-662.

Jenkins, D.W. 1983. Neotropical Nymphalidae. I. Revision of Hamadryas. Bulletin of the Allyn Museum 81: 1-146.

Jenkins, D.W. 1984. Neotropical Nymphalidae. II. Revision of Myscelia. Bulletin of the Allyn Museum 87: 1-64.

Jenkins, D.W. 1985a. Neotropical Nymphalidae. III. Revision of Catonephele. Bulletin of the Allyn Museum 92: 1-65.

Jenkins, D.W. 1985b. Neotropical Nymphalidae. IV. Revision of Ectima. Bulletin of the Allyn Museum 95: 1-30.

Jenkins, D.W. 1986. Neotropical Nymphalidae. V. Revision of Epiphile. Bulletin of the Allyn Museum 101: 1-70.

Jenkins, D.W. 1987. Neotropical Nymphalidae. VI. Revision of Asterope (= Callithea Auct.). Bulletin of the Allyn Museum 114: 1-66.

Jenkins, D.W. 1989. Neotropical Nymphalidae. VII. Revision of Nessaea. Bulletin of the Allyn Museum 125: 1-37.

Jenkins, D.W. 1990. Neotropical Nymphalidae. VIII. Revision of Eunica. Bulletin of the Allyn Museum 131: 1-177.

Kaminski, L.A., Dell'Erba, R. \& Moreira, G.R.P. 2008. Morfologia externa dos estágios imaturos de heliconíneos neotropicais: VI. Dione moneta moneta Hübner (Lepidoptera, Nymphalidae, Heliconiinae). Revista Brasileira de Entomologia 52: 13-23.

Klots, A.B. 1956. Lepidoptera, p. 97-110. In: Tuxen, S.L. (ed.). Taxonomists' glossary of genitalia in insects. Copenhagen, E. Munksgaard, $283 \mathrm{p}$.

Lamas, G. 1995. Comentarios taxonómicos y nomenclaturales sobre ninfálidos neotropicales (Lepidoptera: Nymphalidae), con la descripción de ocho subespecies nuevas. Revista Peruana de Entomología 37: 59-71.

Lamas, G. 2004. Checklist: part 4A. Hesperioidea - Papilionoidea. In: Heppner, J. B. (Ed.) Atlas of Neotropical Lepidoptera, Volume 5A, Gainesville, Association for Tropical Lepidoptera, Scientific Publishers, 439 p.

Leite, L.A.R., Casagrande, M.M. \& Mielke, O.H.H. 2010a. External Morphology of the Adult of Heraclides anchisiades capys (Hübner, [1809]) (Lepidoptera - Papilionidae). I. Head, cephalic appendages and cervical region. Brazilian Archives of Biology and Technology 53: $1119-1126$

Leite, L.A.R., Casagrande, M.M. \& Mielke, O.H.H. 2010b. External Morphology of the Adult of Heraclides anchisiades capys (Hübner, [1809]) (Lepidoptera - Papilionidae). II. Thorax and thoracic appendages. Brazilian Archives of Biology and Technology 53: 1407-1416.

Leite, L.A.R., Casagrande, M.M. \& Mielke, O.H.H. 2011. External Morphology of the Adult of Heraclides anchisiades capys (Hübner, [1809]) (Lepidoptera - Papilionidae). III. Abdomen. Brazilian Archives of Biology and Technology 54: 331-336.

Matsuda, R. 1965. Morphology and evolution of the insect head. Memoirs of the American Entomological Institute 4: 1-334.

Matsuda, R. 1970. Morphology and evolution of the insect thorax. Memoirs of the Entomological Society of Canada 76: 334-355.

Matsuda, R. 1976. Morphology and evolution of the insect abdomen: with special reference to developmental patterns and their bearings upon systematics. Oxford, Pergamon Press, viii +534 p.

Mielke, C.G.C. 1994. Papilionoidea e Hesperioidea de Curitiba e seus arredores, Paraná, Brasil, com notas taxonômicas sobre Hesperiidae. Revista Brasileira de Zoologia 11: 759-776.

Mielke, C.G.C., Mielke, O.H.H. \& Casagrande M.M. 2004a. Estudo comparado de morfologia externa de Zaretis itys itylus (Westwood) e Agrias claudina anneta (Gray) (Lepidoptera, Nymphalidae, Charaxinae). I. Cabeça, apêndices e região cervical. Revista Brasileira de Zoologia 21: 357-369.

Mielke, C.G.C., Mielke, O.H.H. \& Casagrande M.M. 2004b. Estudo comparado da morfologia externa de Zaretis itys itylus (Westwood) e Agrias claudina anneta (Gray) (Lepidoptera, Nymphalidae, Charaxinae). II. Tórax e apêndices. Revista Brasileira de Zoologia 21: 421-433.

Mielke, C.G.C., Mielke, O.H.H. \& Casagrande M.M. 2004c. Estudo comparado de morfologia externa de Zaretis itys itylus (Westwood) e Agrias claudina annetta (Gray). (Lepidoptera, Nymphalidae, Charaxinae) III. Abdome. Revista Brasileira de Zoologia 21: 905-912.

Miller, J.S. 1987. Phylogenetic studies in the Papilioninae (Lepidoptera: Papilionidae). Bulletin of the American Museum of Natural History 186: $365-512$

Miller, J.Y., Miller, L.D., Leysner, B.T. \& Debrot A.O. 1999. The butterfly fauna of Curaçao, West Indies: 1996 status and long-term species turnover. Caribbean Journal of Science 35: 184-194.

Neild, A.F.E. 1996. The Butterflies of Venezuela. Part I: Nymphalidae (Limenitidinae, Apaturinae, Charaxinae). London, Meridian Publications, $144 \mathrm{p}$.

Niculescu, E.V. 1978. L'armature génitale chez les Lépidoptères. Bulletin de la Société Entomologique de Mullhouse (Suppl.): 1-40.

Paluch, M., Casagrande, M.M. \& Mielke, O.H.H. 2008. Morfologia externa do adulto de Actinote melanisans (Lepidoptera: Heliconiinae: Acraeini). Revista Brasileira de Zoologia 25: 456-478.

Pierce, F.N. 1914. The genitalia of the group Geometridae of the Lepidoptera of the British Islands: An account of the morphology of the male clasping organs and the corresponding organs of the female. Liverpool, F.N. Pierce, $x x i x+83$ p.

Scoble, M.J. 1992. The Lepidoptera: form, function and diversity. Natural History Museum Publications. Oxford University Press, 404 p.

Snodgrass, R.E. 1935. Principles of insect morphology. New York, McGraw-Hill, 667 p.

Sorensen, J.T. 1980. An integumental anatomy for the butterfly Glaucopsyche lygdamus (Lepidoptera: Lycaenidae): a morphological terminology and homology. Zoological Journal of the Linnean Society 70: $55-101$.

Srivastava, K.P. 1965. Studies on the lemon butterfly Papilio demoleus L. (Lepidoptera). Part V. Skeleto muscular system of the abdomen. Zoologischer Anzeiger 177: 217-236.

Torre-Bueno, J.R. de la. 1989. The Torre-Bueno glossary of Entomology. Rev. Ed. New York, New York Entomological Society, American Museum of Natural History, $840 \mathrm{p}$.

Wahlberg, N., Weingartner, E. \& Nylin, S. 2003. Towards a better understanding of the higher systematics of Nymphalidae (Lepidoptera: Papilionoidea). Molecular Phylogenetics and Evolution 28: 473-484.

Wahlberg, N., Brower, A.V.Z. \& Nylin, S. 2005. Phylogenetics relationships and historical biogeography of tribes and genera in the subfamily Nymphalinae (Lepidoptera: Nymphalidae). Biological Journal of the Linnean Society 86: $227-251$

Willmott, K.R. \& Hall, J.P.W. 2010. A new species of Dynamine Hübner, [1819] from northwestern Ecuador (Lepidoptera: Nymphalidae: Biblidinae). Tropical Lepidoptera Research 20: 23-27. 